ERCIYYS AKADEMİ, 2021, Özel Sayı, 742-768

https://doi.org/10.48070/erciyesakademi.970746

\title{
POST-TRUTH DÖNEM VE TWITTER KULLANICILARININ HAKİKATE BAKIŞI ÜZERİNE BİR ARAŞTIRMA*
}

\author{
Esra YILDIRIMa
}

DEmel TANYERİ MAZICI ${ }^{\mathrm{b}}$

\begin{abstract}
Özet
Türkçe'ye "gerçek sonrası" veya "hakikat sonrası" olarak çevrilen post-truth kavramı kamuoyu oluşturmada nesnel verilerin kişisel duygu ve kanaatlerden daha az etkili olmasına karşılık gelmektedir. Bu dönemde duyguların harekete geçirilmesiyle hakikatleri değil algıları temel alan sahte bir evren üretilmektedir. Oluşturulan bu zeminde belirli boyutlarda algılanan gerçeklik asıl önemini yitirmekte ve bireylerin hakikate verdikleri önemin derecesi azalarak yalan söylemek sıradanlaşabilmektedir.

$\mathrm{Bu}$ araştırmada sosyal medya kullanıcılarının hakikate verdikleri önemin ve bu bireylerin hakikat algılarının bir sosyal paylaşım sitesi olan Twitter kullanıcıları üzerinden araştırılması amaçlanmaktadır. Bu kapsamda nitel araştırma veri toplama yöntemlerinden derinlemesine mülakat metodu kullanılarak Twitter kullanıcısı 48 kişi ile yarı yapılandırılmış soru formuna bağlı kalınarak bir araştırma gerçekleştirilmiştir. Araştırma posttruth dönemin ortaya çıkışında etkili olan medya aracılığıyla sunulan genelde yalan ya da yanlış bilgi ve içeriklerin insanlar tarafından sadece verilen şekilde alınması ve gösterilen şekilde görülmesi durumunu irdelemiştir. Araştırma sonucuna göre katılımcıların Twitter'da yer alan gerçekliğe şüphe ile yaklaştıkları ve bu ortamda yer alan bilgiye ve kullanıcılara karşı bir güvensizliğin hâkim olduğu görülmüştür. İlaveten katılımcıların bilgilerin doğrulanmasıyla ilgilenmedikleri ve bu konuda hassasiyet duymadıkları sonucuna ulaşılmıştır. Ayrıca toplumsal düzlemde yalanın yaygın olduğu düşüncesinin kullanıcılarda hâkim olduğu görülmüş, bu durumun kurumların hedef kitleleriyle karşılıklı ilişki ve iletişim yönetiminde güven sağlama noktasında dikkate alınmasının önem taşıdığı sonucuna varılmıştır.
\end{abstract}

Anahtar Kelimeler: Post-Truth, Hakikat sonrası, Gerçeklik, Twitter

染海

\section{A RESEARCH ABOUT THE POST-TRUTH PERIOD AND TWITTER USERS' PERSPECTIVE TO THE} TRUTH

Abstract

Translated into Turkish as "post-fact" or "post-truth", the concept of post-truth refers to the fact that objective data is less effective than personal feelings and opinions in forming public opinion. A false universe is

\footnotetext{
Bu makale, Erciyes Üniversitesi Sosyal Bilimler Enstitüsü Halkla İlişkiler ve Tanıtım Anabilim Dalı'nda kabul edilen yüksek lisans tez çalışmasından üretilmiştir.

a Yük. Lis. Öğr, Erciyes Üniversitesi, Sosyal Bilimler Enstitüsü, Halkla İlişkiler ve Tanıtım Anabilim Dalı, eyildirim20@hotmail.com

b Doç. Dr., Erciyes Üniversitesi, İletişim Fakültesi, Halkla İlişkiler ve Tanıtım, etanyeri@erciyes.edu.tr

Makale Geliş Tarihi: 13.07.2021, Makale Kabul Tarihi: 27.07.2021
} 
produced from this world, based not on the quality of education, but on perceptions. On this created ground, the reality perceived in certain dimensions loses its main importance and the degree of importance that individuals attach to the truth decreases and lying can become ordinary.

In this research, it is aimed to research on the importance of social media users' perceptions of truth through a social networking site Twitter users. In this context, a research was carried out with 48 Twitter users using the in-depth interview method, one of the qualitative research data collection methods, by adhering to the semi-structured questionnaire. The research has examined the situation that people generally receive false or false information and content, which is effective in the emergence of the post-truth period, and see it as shown. According to the results of the research, it was seen that the participants approached the reality on Twitter with suspicion and a distrust of the information and users in this environment was dominant. In addition, it was concluded that the participants were not interested in the verification of the information and did not feel sensitive about this issue. In addition, it was seen that the idea that lies are widespread on the social level prevailed in users, and it was concluded that it was important to take into account the importance of providing trust in mutual relations and communication management with the target audiences of institutions.

Keywords: Post-Truth, Truth, Reality, Twitter

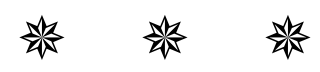

\section{Giriş}

Medyanın ideoloji ve sahiplik yapısına göre belirlediği eksen şimdilerde yeni medya yoluyla farklı bir ortam yaratmaktadır. Özellikle inşa edilen gerçeklik ana akım medya ve yeni medya ortamlarında farklı temsiller edinebilmektedir. Gerçeğin yeniden kurgulanması ve işlenmesi suretiyle algıların şekillendirilmesinde özellikle sosyal mecralar önemli bir yer edinmektedir.

İletişim teknolojilerinde yaşanan değişimle, gerçekleşen olayların yorumlanma biçiminde ve meselelere bakış açısında farklılıklar oluşmaktadır. Nitekim bu durum pek çok faydanın yanında çeşitli zorlukları ve tehditleri de beraberinde getirmektedir. Algılar olguların yerine geçmekte, kurgu ile hakikat arasındaki çizgi silikleşmektedir.

Bu bağlamda her geçen gün kavram dünyasına daha önce bilinmeyen kelimeler eklenmektedir. Bunlardan biri olarak Türkçe 'ye "Gerçek Sonrası" veya "Hakikat Sonrası" olarak çevrilen post-truth kelimesi 2016 yılında Oxford Sözlükleri tarafından yılın kelimesi olarak ilan edilmiştir. Kavram insanların gerçeklerden çok duygu ve inançlara önem vermesini ifade etmekte, gerçeklerin önemsizleştiği bir döneme işaret etmektedir (Oxford Learner's Dictionary, 2020).

Özellikle postmodern dünyaya ait görüşlerin çıkış noktası olarak görünen sadece edebi metinlerin değil aslında geniş yelpazede günümüzde pek çok şeyin metin olarak yorumlanabileceğini düşünmek, içinde bulunulan bu dönemin doğrular ya da yanlışlardan çok anlatılar üzerinde temellendirilmesine neden olmuştur. Bu süreçteyse dil ve ideoloji ilişkisi hakikatin altının oyulduğu ve önemsizleştirildiği bir ortamı doğurmuştur (McIntyre, 2019, ss. 118-119).

Post-truth (hakikat sonrası) dünyada bireylerin yaşadığı olaylara bakış açısı rasyonel olmaktan daha çok kişisel duygu ve düşüncelere dayalıdır. Bu durumda bireyler olay, olgu ve düşüncelere yönelik verilere dayalı bilgi ve mesajlarda verileri kontrol etme, doğrulama ihtiyacı duymamaktadır. Duygular 
ve inançlarla hareket ediliyor olması, analitik çözümlemeyi öldürmekte, dolayısıyla da kalıplaşmış görüşler sorgulanmadan onaylanan bir hâl almaktadır. Artık bireyler kendi inanç, yargı ve kanaatlerine uygun düşen bilgileri doğru olarak kabul etmekte ve yeni medya teknolojileri vasıtasıyla tekrar tekrar dolaşıma sokma imkânı bulmaktadırlar. İnançlar, yargılar ve kanaatlerin aklın önüne geçtiği bu dönemde hakikatin önemsizleştiği görülmektedir. "Hakikat sonrası" kavramı hakikatin önemini yitirdiği bir dönem anlamina gelmektedir.

Hakikat sonrası dönemin ortaya çıkmasında, yoğun veri akışı içerisinde yeterince kontrol mekanizması sağlanamaması ve özellikle sosyal mecraların hakikat olmayanı gerçek olarak sunabilme durumu nedeniyle bireylerin algıları üzerinde etkili olan yeni medya ve yeni medya içerisinde hakikat kavramının yeri bu çalışmanın literatür bölümünde yer almaktadır.

Hakikatin önemini yitirerek değersizleşmesi, aslında gerçek ve ona yönelik yargılar arasındaki uygunluğun yok olması ve bunun artık umursanmamasına işaret etmektedir. Yalanın sıkça kullanılıyor olmasından ziyade, kitlelerin bu duruma verdiği tepki daha önemli olmaktadır. Hakikatin önemsizleşmesiyle birlikte artık kitleler, kendi önyargıları, görüşleri ve kanaatleriyle uyumlu olduğu sürece, yalanın farkında olsa dahi, onları hakikatmiş gibi kabul edebilmektedirler. Yalan olduğu açık bir şekilde ortada olan söylemler karşısında kitleler, yalanları sanki doğruymuşçasına kabul etmekte ve savunmaktadırlar.

Bu bağlamda çalışma, uygulama bölümünde sosyal medya kullanıcıları açısından hakikatin ne anlam ifade ettiği üzerine yoğunlaşmaktadır. Post-truth dönemde hakikat algısının ne noktaya ulaştığ ve sosyal medya kullanıcılarının hakikati nasıl algıladıklarını belirlemek çalışmanın amacını oluşturmaktadır. Bu kapsamda Twitter Kullanıcılarının Hakikat Algıları Üzerine Bir Araştırma'yı konu edinen araştırma bölümünde haber kategorisi içerisinde değerlendirilen, yalan haberler ve alg1 yönetimi uygulamaları ile sık karşılaşılan bir sosyal platform olan Twitter'ın aktif kullanıcılarının hakikat algılarına yer verilmiştir. Yapılan araştırma nitel araştırma yöntem ve teknikleri kullanılarak fenomenolojik araştırma deseni çerçevesinde gerçekleştirilmiştir. Araştırmada Kayseri ili sınırları içerinde yaşayan 48 Twitter kullanıcısı ile yarı yapılandırılmış görüşme yoluyla veriler elde edilmiştir. Araştırma sonucunda elde edilen veriler NVivo12 programı yoluyla analiz edilmiş ve bazı bulgulara ulaşılmıştır. Elde edilen sonuçların akademik literatüre katkı sağlamasının yanı sıra hedef kitlesi ile olumlu ilişkiler kurma amacı taşıyan kişi ve kurumlar açısından fikir sağlaması noktasında önemli olacağ 1 düşünülmektedir.

\section{A. POST-TRUTH DÖNEM VE HAKİKAT KAVRAMI}

Post-truth kavramının dünyada yaygın bir şekilde dolaşıma girmesi 2016 yılında Oxford Sözlükleri tarafından yılın sözcüğü seçilmesi ile gerçekleşmiştir. Oxford Sözlükleri açıklamasında post-

| 744 | truth sözcügüünün son on yıldır var olmasına karşın Birleşik Krallık'ta gerçekleştirilen AB referandumu (Brexit) ve ABD'deki başkanlık seçimiyle etkili olduğunu ifade etmiştir. Oxford Sözlükleri, post-truth'u, "kamuoyunu şekillendirmede, objektif gerçeklerin, nesnel olgularm, duygular ve kişisel kanaatlerden daha az etki etmesi durumuyla ilgili veya bunlara işaret eden" şeklinde tanımlamıştır. Post-truth sözcügündeki post ön eki sıradan kullanımda bir olay ya da durum sonrasını belirtirken; bu kavramda post ön eki, ek olarak 
geldiği kavramın önemsiz veya önemsiz hale geldiği bir zamana ait olduğu anlamını taşımaktadır (Oxford Languages, 2020).

Mantığın asıl ekseninden kayması ve safsatalarla bilinçlerin muğlaklaştırılması post-truth dönemin temel altyapısını oluşturmaktadır. Modernizmin rasyonel bakış açısından ve doğrulamayanlışlama kaygısından uzak bu süreçte duygu ve inançların hakimiyeti hakikatin önemsizleşmesine zemin hazırlamaktadır (Alpay, 2019).

Bireysel algıların, inançların veya görüşlerin nesnel olgulara üstünlüğünün ifade edildiği bu kavramda kavramın sebeplerine ait çıkarımlarda bulunulmamaktadır. Bu açıdan bakıldığında "posttruth" için önerilen karşılıklardan biri olan "hakikatin önemsizleşmesi" kavramı iyi açıklayan bir tanım olarak görülmektedir (Terzi, 2020, ss. 83-84).

Bu noktada hakikat kavramının ne olduğunu anlamak da önem taşımaktadır. Hakikat sözcüğü Arapça kökenli bir sözcük olup hak ve hakikat kavramlarının birleşiminden meydan gelmektedir. İnkâr edilemeyecek derecede sabit olmak anlamına sahip olan bu kelime varlık, düşünce, inanç ve eylemler için de kullanılabilmektedir (Fazlığlu, 2014).

Nitekim "Post-truth" kelimesi Türkçe'ye "hakikat sonrası" ya da "gerçek sonrası" olarak çevrilmektedir. Hakikat ve gerçek kelimeleri ise kavramsal olarak birbiri yerine kullanılmakta ve çoğunlukla birbiriyle karıştırılmaktadır.İngilizce "truth" kelimesinin Türkçe karşılığ1 “hakikat”, İngilizce "reel" kelimesinin Türkçe karşılığı ise "gerçek"tir (Dictionary Cambridge, 2020). Bu terimler arasında felsefî ve dilbilimsel açıdan farklılıklar olduğu bilinmektedir.

Cevizci (2005, s. 793), Paradigma Felsefe Sözlüğ̈̈nde hakikati (İng. Truth, Fr. Verite, Alm. Wahrheit), 1.En genel anlamda dini, bilimsel, ahlaki vb. hakikatler ekseninde bir bilgi alanı ya da disiplininin konu edindiği varlık alanıyla ilgili temel doğrular bütünü. 2.Özel olarak gerçeklik ya da doğruluk anlamında kullanılan ve gerçekte bir şeyin kendi özü içinde örtüsünü açarak vukua gelmesi ve insanın bunun farkında olması durumu olarak tanımlamıştır.

Hançerlioğlu'na (2016) göre ise gerçeklik somuttur, sınanabilir dolayısıyla doğrulanabilir veya yanlışlanabilir. Hakikatse sınanmayan, test edilemeyen ve hatta yanlışlanamayan şeyleri kapsar. İçeriği nesneldir ve insanlar tarafından yaratılamaz. İnsanlar herhangi bir hakikati yaratamayacakları gibi keyiflerine göre değiştiremezler. Hakikat, gerçeğin zihindeki yansıması olduğundan düşünce ile onun nesnesi arasındaki uygunluğu dile getirmektedir. Buna göre elinizde tuttuğunuz kalem gerçek, onun zihninizdeki yansısı hakikattir. Yani bir anlamda somut ve nesnel olarak var olan gerçek iken, gerçekliğin bilinçteki yansıması hakikattir.

$\mathrm{Bu}$ açıdan hakikati ve hakikate yüklenen anlamı bilmek bulunan dönemin koşullarını anlamlandırmak açısından önem taşımaktadır. Hakikate verilen önemin değerini kaybetmesi de hakikat sonrası bir dönem yaratmaktadır. 


\section{B. POST-TRUTH DÖNEMDE SOSYAL MEDYA VE HAKİKAT İLIŞKİSİ}

Sosyal medya, yoğun etkileşimi içeren yeni medya biçimlerini ifade etmek için sıklıkla kullanılan (Manning, 2014), kullanıcılara enformasyon, düşünce ve bilgi paylaşım imkânı tanıyarak etkileşim sağlayan çevrimiçi ortamlar ve web siteleri olarak tanımlanabilir (Sayımer, 2008, s. 123). Keyes'e (2017) göre modern teknoloji hakikat sonrasına uygun bir zemin hazırlamıştır, medya ise hakikat sonrası çağı mümkün kılan başlıca etkenlerden biri olmuştur. Özellikle sosyal medya aracılığıyla kamuoyunu gerçeklerden çok kanaatler ve duygular belirlemekte, yalan ve aldatma gündelik refleksler haline gelmektedir. Siyasette ve toplumsal yaşamda yalan yaygın bir hal almış dürüstlük ise değerini yitirmiştir.

Nitekim hakikatin önemini yitirmesi ve yalan haberin yayılmasında sosyal medyanın yükselişi önemli bir yere sahiptir. Bu süreçte haber ve kanaat arasındaki çizginin muğlaklaşması ve insanların nereden ve ne derece doğru olduğu bilinmeyen bilgileri düşünmeden paylaşması bireylerin içeriklere doyması ve gerçeği aramadan doğrulardan sapmasında etkili olmaktadır (McIntyre, 2019, ss. 91-95).

$\mathrm{Bu}$ yeni medya ortamında hakikatin itibarsızlaşmasına yetecek pek çok argümanın olması kolaylı̆̆ının karşısında yalanı itibarsızlaştırmanın mümkün olmaması hakikat sonrasının ortaya çıkışında etkili olmuştur (McIntyre, 2019). Özellikle, belirli yasalar ve kurallar çerçevesinde kontrol edilebilirliği, her zemin ve her ülkede farklılık gösteren sosyal ağlar, bazı suçlar dışında (şiddet, terör vb.) yer alan içeriklerin kontrolsüz bırakılmasına neden olmaktadır. Yanıltıcı, doğruluğu olmayan, manipülasyon amaçlı üretilen içerik ve metinler, sahte haber, görsel ve videolar bu ağlarda dolaşıma sokulmaktadır. Hakikat sonrası dönemin belirleyicilerinden olan kasıtlı, doğrulanmayan, çoğu zaman da doğruluğu kontrol edilemeyen yalan içerik ve yanıltıcı bilgiler medya platformlarında doğru ve gerçek olarak kullanıcıların algısına sunulmaktadır.

$\mathrm{Bu}$ doğrultuda medyanın ve kitle iletişim araçlarının modern dönemlerde kitleleri yönlendirme etkisi yeni medya araçları ile dönüşüme uğramış, kitle algısı da bu doğrultuda değişim yaşamıştır. Özellikle Twitter, Facebook gibi sosyal ağ sitelerinden yayılan milyonlarca içerik şaşkınlık veren bir boyuta ulaşmakta pek çoğu gerçek olmayan bilgi barındıran bu içerikler kaynağı sorgulanmadan kitlelerce paylaşılabilmekte ve kabul görmektedirler. Bireyler tarafından sosyal ağ sitelerinde oluşturulan ve sosyal çevrede meydana gelen etkileşim ile sosyal medya kullanıcıları kendi duygu ve düşüncelerine hitap eden, oluşturdukları sosyal çevrede itibar gören paylaşımları doğru ya da gerçek olmasa bile kabullenebilmekte ve paylaşabilmektedirler. Bu ortam kullanıcıların kendi düşünce ve duygularına hapsolduğu bir yankı odasına girmelerine neden olmakta büyük kitlelerce paylaşılan bilgilerin yanlış olma ihtimalinin düşük olduğu kabul edilerek, doğruluk payının yüksek kabul edilmesi sonucunu doğurmaktadır. Sosyal ağlarda yayılan bu bilgilerin her birinin araştırılması ve doğrulanması mümkün olmadığından kişilerin hakikat algısı menfi yönde etkilenmekte ve bu durum birey algısında gerçeğin neredeyse buharlaştığı duygusu oluşturmaktadır. İnsanların kendi düşüncelerine benzer düşünceleri aradıkları, kendileri ile benzer düşünceye sahip insanları dinledikleri farklı bir düşüncenin yer edinemediği yankı odalarından çıkarak yayılan sahte haberler, yanlış bilgiler ve sosyal medya yalanları hakikat ötesi çağda toplumun gerçekleri haline gelmektedir (Şimşek \& Yalı, 2019). 
Öyle ki, yeni medya çağında gelen bilginin doğruluğunu öğrenmek için harcanan vakit, yanlış bilginin yayılma hızından çok daha yavaştır. Bu nedenle sosyal medya ve iletişim araçları ile yayılan enformasyonu hakikat süzgecinden geçirmeden kabul etmek toplum ve bireyler üzerinde olumsuz etkiler oluşturmaktadır (Gülmen, 2020).

Bu bağlamda modernizm ile gelişen ana akım medya ulusaldan uluslararası boyuta erişmiştir. Hakikate ulaşmak için entelektüellerin yönetiminde olan ana akım medya düzeninde yalan, safsata ve çarpıtma yine yapılmaktaydı fakat yayınlanan sahte haberler desteklenmek için olgusal verilere dayandırılarak rasyonel bir zeminde oturtulmaya çalıştırmaktaydı. Bu noktada ana akım medya hakikat sonrası çağın ortaya çıkışını engelleyen bir mekanizma görevi görmekteydi. Medyanın yeni teknolojilerle birlikte getirdiği değişim post-truth çağın ortaya çıkmasının önemli sebeplerinden biri olmuştur. Bu platformda haber kaynaklarının yayılarak çoğalması, yalanların, söylentilerin ve dedikoduların ulaşabileceği daha geniş bir alan sağlamıştır. Ana akım medyaya kıyasla insanlar arasında paylaşılan çevrimiçi (online) yalanlar anında hakikat görünümüne bürünebilmektedirler. Artık bireyler tarafından genel kabul görmüş inançlar ile çelişen bir kanıt ortaya atıldı̆̆ında bireyler kanıtı kabul etmekten ziyade hakikatleri görmezden gelmektedirler (Alpay, 2019, s. 41).

Esasen iletişim olanaklarının bu denli arttığı bir ortamda ters bir biçimde hakikate ulaşmanın daha zorlaşmış olması (Bıçakçı, 2016) post-truth dönemin ironisi olarak da görülebilmektedir.

Öyle ki, internetin keşfiyle sosyal medya algı ve gündem oluşturmada başat konuma yükselmiştir. Bu platformlar üzerinden yayınlanan bilgi, fotoğraf, video görüntülerinin küresel boyutta yayılma ve kitleleri etki altına gücü önemli sonuçlar doğurmaktadır. Bu aşamada sosyal medya kullanıcılarının büyük çoğunluğunun bilinç düzeyinin düşük olması da amaç dışı kötüye kullanımın artmasına neden olmaktadır (Gönenç, 2018, ss. 127-128). Özellikle son yıllarda iklim değiş̧ikliği, aşı ve evrim gibi konularda bilimin inkâr edildiği yaklaşımlar hakikatin ön yargılarla istismar edilişini (McIntyre, 2019, s. 34) göstermektedir. Ayrıca sosyal medyada yoğun olarak vuku bulan bilginin tahrifatı ve tahrif olmuş bilginin çarpan etkisiyle yayılımı (Şimşek \& Yalı, 2019, ss. 80-120) sosyal medyanın temel amacından uzak kullanımına işaret etmektedir.

Aslında sosyal medyada algı yönetmek tesadüf olmaktan çok geniş anlamda psiko-sosyolojik analize dayanmaktadır. Özellikle bu süreçte birden fazla enstrümanın ve tekniğin kullanıldı̆̆ı ve süreklilik gerektirdiği görülmektedir. Demografik ve toplumsal özelliklere göre farklı stratejilerin oluşturulması, kültürel dinamiklere göre simge, sembol ve ritüellerin farklılaştırılması (Eraslan, 2020, ss. 122-127) hakikatin kendi zemininden uzaklaştırılabileceğini göstermektedir. Zihinlerin safsataların etkisinde kalmasında bilgi- bilinç-dikkat eksikliği, muhakeme yeteneğinin karışması, önyargı, hırs, ego, manipüle etme isteği ve daha çok kültürel arka plandan kaynaklanan bir takım dışsal nedenler etkili olabilmektedir (Alpay, 2019, ss. 105-109).

Bununla birlikte dijitalleşen dünyayla dijitalleşen kimliklerde algıların yeniden şekillendirilmesinde sosyal medya platformları dezenformasyon ve manipülasyon yaratmaya oldukça elverişli platformlar haline gelmiştir (Göksu, 2021, ss. 22-30). Bu noktada hakikat sonrası dönemi daha 
iyi anlamaya yardımcı olacak, dezenformasyonun ve manipülasyonun hem nedeni hem de sonucu olabilecek birtakım kavramlardan da kısaca bahsedilebilir:

-Filtre Balonu: Web taramaları yapan bireylerden edinilen bilgilerin kişiselleştirilmiş bir dünya yaratmasıyla her kişinin kendi zevk, beğeni, duygu ve düşüncelerine ait adeta kişiye özgü bir balon haline dönüşmesini ifade etmektedir. Bu süreçte kendinden gelen benzer bilgilerle beslenen kişiler içinde bulunduğu sosyal grupların aidiyeti içinde mevcud statükosunu devam ettirmektedir (Pariser, 2011).

-Yankı Odası: Metaforik bir tanımlama olan bu kavramda bireyler farklı fikir, görüş ve paylaşımlara kapalıdırlar. Farklı düşüncelerin ve paylaşımların adeta sansürlendiği bu ortamda birey kendine ait ya da kendine çok benzeyen çıtıların yankı ve yansımalarıyla beslenmektedir (Cinelli, 2021).

- Deep Fake: Sahte içeriklerin oluşmasında da etkili olduğu düşünülen bu kavram özellikle gelişen teknoloji ve yapay zekâ uygulamalarıyla kişilerin mevcud görüntülerinin farklı görüntülerle değiştirilebildiği, ses ve görüntü taklidi yoluyla müdahale edilmiş videoların yaratıldığı gerçeküstü bir uygulamadır (Westerlund, 2019).

-Sanal Gerçeklik: Üç boyutlu uygulamalarla katılımcılarına gerçekmiş hissi veren sanal benzetim modelleridir. Tip, eğitim, eğlence, oyun gibi pek çok alanda kendine yer bulan bu kavram (Bayraktar ve Kaleli, 2007), Baudrillard (2014)' in simülasyon kavramına da paralel olarak fiziksel ve sanal olarak çok farklı gerçekliklerin üretildiği bir dünya yaratmaktadır.

- Bilim İnkarcılığı: Gerek medyada gerekse gündelik yaşam içerisinde yer alan söylemlerde bilimsel kanıtlardan ziyade daha çok duygular ve kişisel kanaatlerin yansıtılması ve zaman zaman kişisel menfaatlere zarar vereceği düşüncesiyle de bilim ve bilim insanlarının açıklamalarına olan güvenin zayıflamasını ifade etmektedir (McIntyre, 2019, s. 38).

- Doğrulama Yanlılığı: Psikolojide insanın rasyonel karar vermesinde bir yanılgı olarak görülen doğrulama yanlılığı (confirmation bias) kuramına göre kişinin bir düşünceye inanmasının ardından karşısına gelen tüm bilgi ve olayları farkında olmadan bu düşünce ve fikirlerini desteklemek için kullanmasıdır. Doğrulama yanlılığı bireylerin kendi duygu, düşünce ve inançlarını pekiştiren, onları doğrulayan ve destekleyen bilgi ve enformasyonun aranmasıdır (Psikoloji Sözlüğü, 2021).

- Postmodernizm: Postmodern görüş, insan algısından bağımsız olarak var olan nesnel bir gerçekliği reddederek bilginin sınıf, ırk, cinsiyet ve diğer değişkenlerin süzgecinden geçerek oluştuğunu iddia etmektedir. Nesnel gerçeklik kavramını reddederek hakikatin yerine bakış açısı ve konumlandırma kavramlarını koymaktadır (Kakutani, 2018, ss. 40-57). Postmodernizmin ideolojik sonuçlarıyla gerçeklik belirsizliğe dönüşürken inkâr genel bir tavır olarak kabul görmekte gerçek dünya popülizme ve reality showa evrilmektedir (Ferraris, 2019).

$\mathrm{Bu}$ kavramların bireyin gündelik hayatı ve toplum hayatında yaygınlaşması hakikat sonrası kavramına geniş ölçekte bakmayı gerektirmektedir. Hakikat ve dezenformasyon kavramlarının birbirlerine olan zıtlığı, hakikat ve hakikate verilen değerin önemini kaybetmesi kendini bu konuda tehdit altında hisseden devletleri ve belli kuruluşları dezenformayonla mücadele eden kurumlar oluşturmaya ve eylem planları hazırlamaya mecbur bırakmaktadır (Güner, 2021). Bununla birlikte bu 
sürecin olumsuz etkilerinin asgariye düşürülüp zaman içinde kaldırılmasında eleştirel bakış açısı önemli bir çıkış noktası olarak görülebilir. Okuduğu ve dinlediği metni sorgulayan, yorumlayıp sebep sonuç ilişkisi kurabilen, metnin asıl amacını ve çıkarımını anlamlandırabilen bireyler büyük veri karşısındaki kafa karışıklığından sıyrılabileceklerdir (Şimşek \& Yalı, 2019, ss. 167-176). Bu açıdan post-truth dönemde edindiği bilgiyi eleştirel biçimde sorgulayıp doğruluğundan emin olan kaynağını, URL adresini, tarihini, başlı̆̆ını karşılaştırabilme yetisi elde etmiş bireyler (Tok, 2020, ss. 478-479) için bir anlamda dijital medya okuryazarı olabilmek ayrıca önemli olmaktadır.

\section{YÖNTEM}

\section{Araştırmanın Amacı ve Önemi}

Hakikatin önemini yitirdiği yeni bir dönem olarak adlandırılan post-truth dönemde sosyal medya kullanıcılarının hakikat algılarının, algı yönetimi uygulamalarının sıklıkla gerçekleştirildiği sosyal medya platformu olan Twitter kullanıcıları üzerinden ortaya konulması araştırmanın amacını oluşturmaktadır. Bu bağlamda çalışma yerli literatürde, post-truth dönemde medya aracılığıyla verilerin ve bilgilerin bireylerin algılarına etkilerini ve bu bağlamda sosyal medya kullanıcılarının özeliklerini gösteren az sayıda çalışma olması nedeniyle önemli olmanın yanında ulaşılan bulguların kurum ve kuruluşlara özellikle halkla ilişkiler uygulayıcılarına hedef kitleleri ile sağlıklı iletişimin yürütülmesi ve sürdürülebilmesi için bir yol haritası sunması açısından önem taşımaktadır.

\section{Araştırmanın Yöntemi}

Sosyal medya kullanıcılarının hakikat algılarının fenomenolojik yaklaşım çerçevesinde anlamlandırmaları, tanımlamaları ve sosyal medya mecralarında gerçeğin inşa edilişine yönelik anlamların incelenmesi amaçlanmıştır. Bu kapsamda nitel araştırma yöntemlerinden olan derinlemesine mülakat tekniği uygulanmıştır.

\section{Araştırma Grubu}

Post-truth dönemde sosyal ağ sitesi kullanıcılarının hakikat algılarını belirleme amacı taşıyan bu araştırmada ulaşılacak özgül bilgilerin yanında, hakikat algısının demografik özelliklere göre nasıl farklar içerebileceğine yönelik olarak da katılımcılar, demografik özellikleri göz önünde bulundurularak farklı gruplardan amaçlı örneklem belirleme yoluyla alınarak bir araştırma grubu oluşturulmuştur. Buna göre Kayseri'de ikamet eden (41-56) yaş arası X kuşağı, (25-40) yaş arası Y kuşağı ve (18-24) yaş arası Z kuşağı olarak sınıflandırılan yaş gruplarından 16'şar ve cinsiyet açısından her gruptan sekiz kadın ve sekiz erkek, toplamda 48 katılımcı araştırma içerisine alınmıştır. Kuşakların sınıflandırılması, literatür değerlendirmesi ve hâkim genel kanıya uygun şekilde Fox 'un (2011, s. 24) sinıflandırması esas alınarak yapılmıştır. Buna göre 1965-1980 yılları arasında doğanlar X Kuşağı, 1981-1995 yılları arasında doğanlar Y Kuşağı ve 1996 yılı ve sonrasında doğanlar ise Z Kuşağı olarak ele alınmıştır. Katılımcılar aktif şekilde Twitter'ı kullanıyor olmaları ön şartı ile araştırmaya dahil edilmiştir. 


\section{Veri Toplama Aracı ve Verilerin Toplanması}

$\mathrm{Bu}$ nitel araştırmada Twitter kullanıcılarının hakikat algılarına ilişkin spesifik bilgilerin elde edilmesi amacıyla, 48 katılımcı ile yarı yapılandırılmış bir form üzerinden birebir görüşmeler gerçekleştirilmiştir. Mülakatlar ortalama 15-20 dakika sürmüştür. Katılımcı izni dahilinde görüşmeler ses kayıt cihazı ile kaydedilmiş, kayıtlar daha sonra deşifre edilerek yazılı metne çevrilmiştir. Bu metinler NVivo12 programı ile cümle bazında ele alınarak analiz edilmiştir. Araştırma açısından anlamlı cümlelerin analizi neticesinde kodlar (program dilinde node'lar) oluşturulmuştur. Bu kodlarla benzer nitelikteki tüm kodlar bir "tema" altında birleştirilmiştir.

\section{Araştırma Soruları}

Araştırma formu sorularında Yalçınkaya vd. (2018)' nin çalışmasından faydalanılmıştır. Yine uzman görüşü alarak yapılandırılan formda gerekli düzeltmelerle son şekli oluşturulmuştur.

Araştırma soruları hakikat/gerçeklik algısı, yankı odası etkisi ve yalan söylemeye bakış açısı olmak üzere üç ana tema üzerinden yapılandırılmıştır. Bu temaların belirlenmesinde post-truth dönemde hakikat ve gerçeklik bağlamında; yalanın söylenmesi fakat buna karşın insanların hakikati bilmeyi istememeleri, gerçekliği bilme düşüncesinin değil bizzat gerçekliğin varlığının hiçe sayılması; yankı odası etkisi bağlamında; Twitter uygulamasının belirli bir algoritma kullanmasının farklı ya da rakip görüşlerin sansürlenmesine neden olabilmesi ve sahip olunan bilgilerin, düşünce, kanaat ve inançların kullanıcıların dijital medya ortamlarında seçtikleri mesajlarla yinelenerek kuvvetlendirilmesi; yalan söyleme bağlamında ise; doğruluğa yeterince önem verilmemesi, yalanların samimiyetle çelişmemesi ve kitlelerin kendi önyargılarına, görüşlerine ya da kanaatlerine uyumlu olduğu sürece, yalanların yalan olduğunu bilse dahi, onları hakikatmiş gibi doğru kabul etmesi, onları savunup sahip çıması etkili olmuştur. Buna göre Twitter üzerinden yapılan paylaşımların insanların hakikat algılarını nasıl yönlendirdiğine dair belirlenen araştırma soruları şu şekildedir:

-Twitter kullanıcıları sosyal medyada hakikati nasıl anlamlandırmaktadır?

- Twitter kullanıcıları bu anlama ulaşırken nelerden etkilenmektedir?

- Twitter kullanıcıları için yalan söylemek ne anlam ifade etmektedir?

6. Verilerin Analizi

Ses kayıt cihazı ile kaydedilen ve yazılı metin haline getirilen veriler NVivo12 programı ile cümle bazında ele alınarak analiz edilmiştir. Araştırma açısından anlamlı cümlelerin analizi neticesinde kodlar (program dilinde node'lar) oluşturulmuştur. Bu kodlarla benzer nitelikteki tüm kodlar bir "tema" altında birleştirilmiştir. Çalışmada ayrıca demografik değişkenler göz önünde bulundurularak demografik veriler üzerinden nicel analiz gerçekleştirilmiştir.

\section{Araştırma Bulguları ve Değerlendirme}

Araştırma içerisine dahil edilen 48 katılımcı ile gerçekleştirilen görüşmelerde katılımcıların günde en az 1 saatlerini Twitter'da geçirdikleri ortalamasına ulaşılmıştır. Katılımcıların Twitter kullanımındaki 
genel amaçların "En Son Haberlerin Takibi" ve "ilgilenilen Konulardaki Trend Topic Gelişmeleri Takip Etmek" oluşturmaktadır. Katılımcıların diğer Twitter kullanım amaçlarını ise "Insanlarla İletişim", "Yazı ve Çalışmaların Paylaşılması", "Boş Vaktin Değerlendirilmesi" ve "Ĕ̆lenmek" oluşturmaktadır.

Katılımcılarla yapılan görüşmelerden elde edilen ve NVivo programı ile analiz edilen veriler "haberin doğruluğu", "paylaşımlarda doğruluk teyidi", "bilgi ve söylenti ayrımı", "Twitter ve gerçeklik", "platform karşılaştırma", "paylaşılan gerçeklik", "yankı odası", "farkl fikirlere tahammül", "çoğunluğun doğrusu", "paylaşımların düşünce değişimine etkisi" ve "yalana bakış" olmak üzere 11 tema altında kodlanmıştır.

Tablo 1. de katılımcıların sosyo-demografik özellikleri görülmektedir. Katılımcıların isimleri gizli tutularak 1'den 48'e kadar numaralandırılmıştır. " $K$ " katılımcıyı, yanındaki sayı ise kaçıncı katılımcı olduğunu gösteren bir sembol olarak kullanılmıştır. Bulgularda katılımcıların söylediklerinin takibinin yapılabilmesi açısından her ifadenin yanında onu kimin söylediğine dair katılımcı numarası, yaş ve cinsiyet bilgisi verilmiştir.

Tablo 1. Katılımciların Sosyo-Demografik Özellikleri Listesi

\begin{tabular}{|c|c|c|c|c|}
\hline Katılımcı Numarası & Cinsiyet & Doğum Yılı & Öğrenim Durumu & Meslek \\
\hline K1 & Erkek & 1972 & Lise & Gazeteci \\
\hline K2 & Erkek & 1964 & Lisans & Gazeteci \\
\hline K3 & Erkek & 1975 & Lise & Memur \\
\hline K4 & Erkek & 1971 & Ön lisans & Memur \\
\hline K5 & Erkek & 1972 & Lisans & Gazeteci \\
\hline K6 & Erkek & 1971 & Ön lisans & Memur \\
\hline K7 & Erkek & 1973 & Yüksek lisans & Öğr. Gör. \\
\hline K8 & Erkek & 1976 & Ortaokul & Hukuk Br. Çal. \\
\hline K9 & Kadın & 1978 & Lise & Basın-Memur \\
\hline K10 & Kadın & 1979 & Lise & Satış Sorumlusu \\
\hline K11 & Kadın & 1969 & Lisans & Memur \\
\hline K12 & Kadın & 1976 & Lisans & Sağlık Çalışanı \\
\hline K13 & Kadın & 1966 & İlkokul & Ev Hanımı \\
\hline K14 & Kadın & 1976 & Ön lisans & Memur \\
\hline K15 & Kadın & 1978 & Ön lisans & Sekreter \\
\hline K16 & Kadın & 1973 & Ön lisans & Sekreter \\
\hline K17 & Erkek & 1994 & Lisans & Memur \\
\hline K18 & Erkek & 1984 & Lisans & Memur \\
\hline K19 & Erkek & 1996 & Yüksek lisans & Öğrenci \\
\hline K20 & Erkek & 1981 & Lisans & Gazeteci \\
\hline K21 & Erkek & 1993 & Ön lisans & Muhabir \\
\hline K22 & Erkek & 1984 & Lise & Gazeteci \\
\hline K23 & Erkek & 1996 & Yüksek lisans & Öğrenci \\
\hline K24 & Erkek & 1995 & Lisans & İşsiz \\
\hline K25 & Kadın & 1991 & Yüksek lisans & Öğrenci \\
\hline K26 & Kadın & 1994 & Lisans & Sağlık Çalışanı \\
\hline K27 & Kadın & 1982 & Lisans & İşsiz \\
\hline K28 & Kadın & 1993 & Yüksek lisans & Öğrenci \\
\hline K29 & Kadın & 1996 & Lisans & İşsiz \\
\hline K30 & Kadın & 1988 & Lisans & Memur \\
\hline K31 & Kadın & 1991 & Lisans & İşsiz \\
\hline
\end{tabular}




\begin{tabular}{lllll}
\hline K32 & Kadın & 1981 & Yüksek lisans & Memur \\
\hline K33 & Erkek & 2001 & Lise & İşsiz \\
\hline K34 & Erkek & 1998 & Lise & İşçi \\
\hline K35 & Erkek & 1993 & Lisans & Memur \\
\hline K36 & Erkek & 2001 & Lisans & Öğrenci \\
\hline K37 & Erkek & 1998 & Lisans & Öğrenci \\
\hline K38 & Erkek & 1996 & Lise & Satıs Sorumlusu \\
\hline K39 & Erkek & 1997 & Lisans & Öğrenci \\
\hline K40 & Erkek & 2000 & Lise & Satış Sorumlusu \\
\hline K41 & Kadın & 1997 & Lisans & İşsiz \\
\hline K42 & Kadın & 2000 & Lise & Öğrenci \\
\hline K43 & Kadın & 2000 & Lise & Öğrenci \\
\hline K44 & Kadın & 2002 & Lise & Öğrenci \\
\hline K45 & Kadın & 1996 & Lisans & Öğralınci \\
\hline K46 & Kadın & 1998 & Lisans & Öğrenci \\
\hline K47 & Kadın & 2002 & Lise & Öğrenci \\
\hline K48 & Kadın & 1999 & Lise & \\
\hline
\end{tabular}

48 katılımcı ile gerçekleştirilen görüşmeler neticesinde, araştırma için anlamlılığı olan toplamda 912 ifade çözümlenmiştir. Anlamlı ifadelerin nasıl kodlandığına ve temalara nasıl ulaşıldığına örnek olması bakımından bir temaya ait analiz ise Tablo 2.'de gösterilmiştir.

Tablo 2. Kodlamalardan Temalara, Analiz Sürecine Bir Örnek

\begin{tabular}{|c|c|c|}
\hline Tema & Kod & Anlamlı İfade \\
\hline \multirow[t]{5}{*}{$\begin{array}{l}\text { Twitter'da Haberin } \\
\text { Doğruluğu }\end{array}$} & İnanma & $\begin{array}{l}\text { "Doğru buluyorum, genelde her şey ilk önce Twitter da yayılıyor.” } \\
\text { (K42) } \\
\text { "İnanıyorum yani \%100 doğru buluyorum." (K44) } \\
\text { "İnanıyorum, bayağı doğru buluyorum, zaten o yüzden Twitter } \\
\text { kullanıyorum."(K30) } \\
\text { "Doğru olduğuna inanıyorum, çünkü genellikle doğru çıkıyor.” (K48) }\end{array}$ \\
\hline & İnanmama & $\begin{array}{l}\text { "Çok çabuk yayılıyor ama doğruluğuna ben inanmıyorum." (K24) } \\
\text { "Hayır hiçbirine inanmıyorum." (K1) } \\
\text { "Hayır inanmıyorum baktığım süre zarfı içinde karşıma çıkan } \\
\text { haberlerin doğruluğuna inanmıyorum." (K15) }\end{array}$ \\
\hline & Kismen inanma & $\begin{array}{l}\text { "Doğru olanlar da var, bir olayı manipüle eden insanlar da var, Twitter } \\
\text { da paylaşılanların geneline baktığım zaman \%60'ının gerçek olduğunu } \\
\text { düşünmüyorum \%40’1 doğru." (K25) } \\
\text { "Kısmen, çünkü birisi okullar kar tatili diyor, öyle bir şey yok." (K34) }\end{array}$ \\
\hline & $\begin{array}{l}\text { Takip edilen ya da paylaşımı } \\
\text { yapan kişilere güven }\end{array}$ & $\begin{array}{l}\text { "Takip ettiğim sayfalar güvenilir kişi ve haber kuruluşları olduğu için." } \\
\text { (K27) } \\
\text { "Kullanıcının kimliği önemli benim için. Tanıdığım güvendiğim bir } \\
\text { kaynağın hesabı ise tabi ki güvenirim, onun dışında sahte kullanıcı ise } \\
\text { itibar etmiyorum haber dışındaki bilgilere çok inanmıyorum." (K5) }\end{array}$ \\
\hline & Kurumsal Kullanıciya Güven & $\begin{array}{l}\text { “Resmi kanalları gördüğüm zaman inanıorum." (K26) } \\
\text { "Resmi kanallardan yapılan haberlerin doğruluğuna inanıyorum." (K9) } \\
\text { “Genelde resmi siteleri takip ediyorum ve onların güvenirliğine \%100 } \\
\text { olmasa da inanıorum." (K19) } \\
\text { “Güvenilir bir kaynak ise bu bakanlık vb. bir siteyse inanıyorum.” } \\
\text { (K38) }\end{array}$ \\
\hline
\end{tabular}




\section{D.BULGULAR}

Analiz sonucu elde edilen bulgular ve bu doğrultuda oluşturulan temalar aşağıda sunulmaktadır.

\section{1. (Tema 1)- Haberin Doğruluğu}

Katılımcıların Twitter'da yer alan haberlerin doğruluğuna dair bakış açları doğruluğuna "inananlar", "inanmayanlar" ve "kısmen inananlar" olarak üç grupta incelenebilir. İnananlar arasında 2000 doğumlu Z kuşağı kadın katılımcı (K42), "Doğru buluyorum genelde Twitter da yayılıyor her şey ilk önce" ifadesi ile Twitter'da yer alan haberin doğruluğuna inanmasında, haberin ortaya çıkışı ve yayılımının ilk olarak Twitter'da olmasının etkili olduğu görülmektedir. İnanmayanlar kategorisindeki 1978 doğumlu X kuşağı kadın katılımcı (K15), "Hayır inanmıyorum baktığım süre zarfı içinde karşıma çıkan haberlerin doğruluğuna inanmıyorum" diyerek Twitter'da geçirdiği süre zarfı içinde karşısına çıkan haberlere çok inanmadığını belirtmiştir. Kısmen inananlar arasında 1991 doğumlu Y kuşağı kadın katılımcı (K25) “Doğru olanlar da var, bir olayı manipüle eden insanlar da var, Twitter da paylaşılanların geneline baktığım zaman yüzde 60'ının gerçek olduğunu düşünmüyorum, yüzde 40'ı doğru, özgür bir ortam, sahte hesap kullanan insanlar var, bazı şeyler çok çarpıtılıyor, küçük bir kaza geçirmiş insan kolu kopmuş olarak çıkabiliyor" diyerek Twitter'da yer alan haberlere olan güvensizliğini dile getirmiştir.

Katılımcı görüşleri genel olarak değerlendirildiğinde, haberin doğruluğuna inanan katılımcılar nezdinde Twitter'da haber paylaşım oranı yüksekliği ve resmi makamların ve resmi unvana sahip kişilerin bu platformlarda yoğun paylaşımı, platformun resmi bir yer olarak algılanmasına neden olmaktadır. Twitter'da yer alan paylaşımı kimin yaptığı, sayfanın kurumsallığı ya da sayfa sahibinin güvenirliği katılımcılar açısından haberin doğruluğuna inanma konusunda da birer etken olmaktadır. Twitter'da yer alan haberin doğruluğuna kısmen inanan katılımcıların sahip oldukları doğruluk algısı bu platformda sahte hesaplarla yapılan paylaşım sıklığı ile yalan, çarpıtılmış ve abartı içeriklerle sıklıkla karşılaşmaları nedeniyle paylaşılan enformasyona karşı şüphe ile yaklaşılması şeklindedir. Twitter'da yer alan hiçbir bilgiye inanmayan katılımcılarda ise Twitter'dan edinilen haber ya da bilginin genelde asılsız çıkmasının etkili olduğu görülmektedir.

\section{2. (Tema 2)- Paylaşımlarda Doğruluk Teyidi}

Post-truth dönemde Twitter gibi sosyal ağ siteleri manipülatif ve provokatif paylaşımların yanı sıra asparagas haberlere aracılık için de kullanılmaktadır. Yalan ya da yanlış bilgi barındıran haberler, çarpıtılmış içerikler kullanııların paylaşımları ile çarpan hızıyla çoğalarak dolaşıma girmekte ve hızlı bir şekilde yayılabilmektedir. Bu tür içeriklerin paylaşımına karşı inisiyatif ve sorumluluk sosyal ağ sitesi kullanıcısının kendisinde bulunmaktadır. Bu noktada Twitter'da katılımcıların karşılarına çıan bir bilgiyi ya da haberi paylaşma hususunda tercihleri "doğruluğundan emin olmadan paylaşmama" ve "doğruluğundan emin olmadan paylaşma" olarak iki grupta incelenebilir.

Doğruluğundan emin olmadan paylaşma hususunda 1996 doğumlu, erkek Y kuşağı katılımcı (K23), "Doğruluğuna emin olmadan paylaşıyorum dikkatimi çekti, okudum, beğendim, paylaşırım, diğer sitelere bakıp da doğru olup olmadığını araştırmam pek" ifadesiyle doğrulama yapmadığını açıklamıştır. 1997 doğumlu, kadın Y kuşağı katılımcı ise (K41), "Yapıyorum onu evet doğruluğundan emin olmasam da o anki 
doğruluğuna inanıyorum." ifadesiyle anlık paylaşımda bulunduğunu ve emin olmasa da doğrulama yapmadığını söylemiştir. Bir diğer katılımcı ise "Evet bu huy bende var, Twitter'a inanıyorum genelde, resmi sayfalar takip ettiğim için retweetlerim" (K28, 1993 doğumlu, kadın, Y Kuşağı) ifadesinde bulunmuştur. Doğruluğundan emin olmadan yapılan kullanıcı paylaşımlarında yukarıdaki katılımcıların belirttiği üzere pek çok katılımcı Twitter' da yer alan habere güven ve inanç, o an oluşan doğruluk algısı, paylaşıma olan dikkat ve ilgi gibi nedenlerle doğrulama yapmamaktadır.

Twitter'da karşılarına çıkan bir bilgi ya da haberi doğruluğundan emin olmadan paylaşmayan katılımcılardan 1991 doğumlu Y kuşağı kadın katılımcı (K25), "Kesinlikle hayır, özellikle Twitter'da ve sosyal medyada doğruluğuna inanmadığım şeyleri paylaşmam." ifadesiyle doğru olmayan bilgiyi paylaşma konusuna olan hassasiyetini dile getirmiştir. Benzer şekilde 1971 doğumlu X kuşağı erkek katılımcı K6' da bu hassasiyeti şu şekilde dile getirmiştir;

“Şimdi ben beğensem de beğenmesem de çok yapmıyorum onu çünkü ben onu yaptığım zaman karşıdaki kişiyi belki yanıltabilirim o açıdan sadece kendim için okuyorum fakat bazı haberler var ki, bazı paylaşımlar var ki, mutlaka yapılması gerekiyor, hani bu milli bir paylaşımdır, ülke meselesi ile alakalı bir paylaşımdır, sosyal bir paylaşımdır ki; yani insanların buna ihtiyacı vardır veya bazı bilgiler içerir, mesela günümüzde covid-19 var, bu tür paylaşımları orada yapıyorum."

Twitter'da yer alan haberin doğruluğunun teyidi hususunda katılımcıların algısında takip ettikleri kullanıcıların güvenilir kişiler olması, resmi sayfa ve resmi sayfa sahibi kişilerin söz konusu haber paylaşımları, diğer kullanıcıların yapılan haberi aynı şekilde yoğun olarak paylaşmaları, diğer sosyal ağ sitesi ve arama motorları ile tarama yaptıklarında haberin aynı şekilde yer alması gibi faktörler ön plana çıkmaktadır. 1993 doğumlu, Y kuşağı kadın katılımcı (K28), "Resmi kaynaksa doğrulamam, Milliyet gazetesi veya mavi tik almış hesap gibi. Ama sıradan bir hesabı doğrularım" diyerek hesap kullanıcısının resmi kimliğini önemsediğini belirtmiştir. 1988 doğumlu Y kuşağı kadın katılımc1 (K30), “Oluyor evet birkaç tane farklı mecrada aynı şekilde paylaşılmışsa doğru olarak görüyorum çok sık RT yapmam ama yaptığım zaman doğruluğuna inandığım için yapıyorum." ifadesiyle doğruluk teyidi yapmadan birkaç kaynakta aynı haberin yer almasına dayanarak paylaşım yaptığını belirtmiştir. Katılımcıların geneli yalan içerik üretimi ve yayımına karşı kurulan doğrulama platformlarının varlığından haberdar olmamakla birlikte haberdar olanların pek çoğu da doğruluk teyidi yapma amaçlı bu platformları kullanmamaktadırlar. Katılımclardan bazıları ise Twitter'da beğeni ve retweet yapmayı çok tercih etmediklerini bu konuda çok seçici olduklarını ifade etmiş, bazı katılımcılar ise Twitter'da sadece okuyucu olduklarını ve sık paylaşım yapmadıklarını ifade etmişlerdir.

\section{3. (Tema 3)- Bilgi ve Söylenti Ayrımı}

Bilgiye erişimin yeni iletişim teknolojileri vasıtasıyla çok daha pratik ve kolay olduğu özellikle

| 754 | sosyal ağların, enformasyonu tüketen bireylerin üretici haline gelmesini kolaylaştırdığı bu dönemde bilgi ve söylenti ayrımının yapılabilmesi ve doğru bilgiye erişimin sağlanması toplumun doğru karar alması ve toplumsal düzenin sağlanması açısından önemli olmaktadır. Twitter'da yapılan paylaşımların bilgi ya da söylenti mi olduğuna yönelik ayrımında katılımcılar, bilgiye yönelik paylaşımlarda bir resmiyet aramakta, paylaşımların içeriğinde kaynak gösterilip gösterilmemesine dikkat etmektedir. Katılımcılar 
nezdinde paylaşımın kim tarafından yapıldığı da önem taşımakta ayrıca bilgi ve söylenti ayrımında katılımcılar kendi bilgi, tecrübe ve sezgilerine güvenmektedir. Resmiyet ve kullanıcı kimliği açısından bilgi ve söylenti ayrımında; 1973 doğumlu X kuşă̆ı erkek katılımcı (K7), "Yayınlayanın kim olduğuna bakarım resmi kuruluş ya da güvenilir bir medya kuruluşu mu ona bakarım" diyerek resmi bir kurum olmasına önem verdiğini belirtmiştir. 1996 doğumlu Z kuşağı erkek katılımcı (K38) ise "bilgi sonuçta belli bir sosyal kurumdan yayılan bir şeydir, söylenti de benim senin ya da X bir kişinin söylediği şeydir o şekilde ayırt edebiliyorum" diyerek resmi bir kurum vasitasılya edinilen enformasyonu bilgi olarak nitelendirerek söylentiden ayırmıştır. 2002 doğumlu Z kuşağı kadın katılımcı (K44) ise "Ayırt ederim, şöyle ki; mesela Sağlık Bakanı Koronavirüs ile ilgili bir açıklama yapıyor, Sağlık Bakanı yaparsa kesin emin olurum ama başka biri yapsa emin olmam şüphe duyarım." ifadesiyle bilgi edinimi noktasında kişisel ve kurumsal resmiyete önem verdiğini belirtmiştir. Twitter'da yapılan paylaşımın kaynağına bakarak bilgi ve söylenti ayrımı yaptığını belirten katılımcılardan 1982 doğumlu, Y kuşağı kadın katılımcı (K27), “Bilgiyse bir kaynăga dayanıyordur, yorumsa söylentidir." diyerek bilginin bir kaynağa dayalı olması gerektiğini düşündüğünü belirtmiştir. 2001 doğumlu, Z kuşağı erkek katılımc1 (K33), "Söylenti şahsi oldŭ̆u için biraz daha kendini belli ediyor ama bilgi kaynak içerdiği için biraz daha ağır basıyor." ifadesi ile paylaşılan içeriklerde kaynak kullanımını ayırt edicilikte ön plana çıkarmıştır. 1988 doğumlu Y kuşağı kadın katılımcı (K30), "Haberde kaynak gösterilmişe daha ciddiye alıyorum bilgi olarak görüyorum, söylenti olarak diğer insanların paylaşımları" diyerek kaynağa dayalı paylaşımları bilgi olarak nitelendirirken diğer kullanıcıların yaptı̆̆ı paylaşımları söylenti olarak değerlendirmiştir.

Bilginin ve bu doğrultuda algının her gün yeniden üretildiği sosyal medya ortamlarında genel olarak katılımcılar Twitter içeriklerindeki bilgi ve söylenti ayrımına dair görüşlerini belirtmişlerdir. Katılımclar içerisinden 1995 doğumlu Y kuşağı erkek katılımcı K24, "Söylenti diyelim oradakine bilgi demeyelim daha çok orada insanlar yorum yapıyorlar kendi görüşlerini belirtiyorlar bilgiden ziyade, bilgi için genellikle Google'ı falan kullanıyorum" diyerek Twitter'da yer alan paylaşımları genelde söylenti olarak nitelendirmiştir. Bu katılımcı düşüncesine benzer şekilde katılımcılar genel olarak Twitter' da yapılan paylaşımlarda bir kaynağa dayanmayan, resmi bir kurum kuruluş ya da kişi tarafından paylaşılmayan, tanınırlık ve bilinirliği olmayan şahsi hesaplardan yapılan paylaşımları bilgi kapsamında değerlendirmemekte, söylenti olarak nitelendirmektedirler.

\section{4. (Tema 4)- Twitter ve Gerçeklik}

Sanal alem olarak nitelendirilen yeni medya ortamları bireylerin gerçeklik algıları üzerinde oldukça etkili olmaktadır. Çoğu kez algılar ve olgular yer değiştirmekte kurgu ile hakikat arasındaki fark ayırt edilememektedir. Katılımcılar sosyal ağ sitesi Twitter'da gerçekliği ve Twitter'da kullanıcı davranışındaki gerçekliği değerlendirmişleridir. Buna göre sayıca fazla olan katılımcılar Twitter'ın içinde yaşanılan gerçek dünyadan farklı olduğunu düşündüklerini belirtmiş, sayıca daha az kısımda olan katılımclar ise gündelik yaşam içerisinde bulunan gerçeklik ile Twitter'da var olan gerçekliğin aynı olduğunu düşündüklerini ifade etmişlerdir.

Twitter'1 günlük yaşamdan farklı bulan katılımcılardan, 1994 doğumlu Y kuşağı erkek katılımcı (K17), "burada sanal bir gerçeklik var, doğru gerçeklikle alakası yok çoğu şeyin, hayatla bir alakası yok" demiştir. 1979 doğumlu X kuşağı kadın katılımcı (K10) “Bazı haberler çok şişirilmiş oluyor, gerçeklik payı çok cüzi 
miktarda oluyor ama üstüne ekleme yapılıyor, ben onları kesinlikle paylaşmıyorum" diyerek Twitter'da yer alan paylaşımların gerçek hayatı çok yansıtmadı̆̆ını belirtmiştir. 1996 doğumlu Z kuşağı kadın katılımcı (K45), "Tabi ki farklı Twitter ortamı ayrı bir dünya benim de şahsen oradaki halimle normal halim bir değil yani" söylemi ile kendi gerçekliği üzerinden Twitter'da var olan gerçekliği değerlendirmiştir.

Bir diğer katılımcı ise Twitter ortamının gerçeklikten uzak olduğunu yaşanan bir olay üzerinden örnek vererek ve kendi deneyimini aktararak belirtmiştir:

“Çok farklı. Bunu bayă̆ı sosyal medyada yaşamışsınızdır, sosyal medyada gerçekten Twitter'da müthiş bir etki tepki oluyor. Bunu seçimlerde yaşadık ama bu seçimlerde sandiğa gitmediler. Dünya Twitter'dan ibaret değil o yüzden Twitter'ı kullanan çok fazla ama kullanmayan da çok fazla o yüzden Twitter'daki sanal alemle gerçek alem arasında çok fark var. Bunları yaşadık örnek verecek olursam; toplumsal bir olay olmuş bir kadına istismar olayı olmuş kadın sosyal medyada Twitter'da inanılmaz derecede çok fazla destek almış, kadın duruşma gününe kadar söyledi bunu, kadına sürekli destek mesajları atıldı duruşmada yanında olacağız vs. dediler, ortalık yıkıldı sosyal medyada, ben duruşmayı takip ettim o Twitter'da ortalı̆̆ı yakıp yıkanlar maalesef duruşma salonunda yoktu, beş altı kişi vardı. Sosyal medyada klavye delikanlılı̆̆ yapanlar gerçek hayatta maalesef yoklar" (K22, 1984 doğumlu, erkek, Y kuşağı).

Twitter'ı gerçek bir ortam olarak nitelendiren katılımcılar bu kanıya genelde Twitter'ı diğer sosyal platformları karşılaştırarak, bireylerin paylaşımlardan yola çıkarak ve Twitter' da güncel haberlerin yer almasına (kaza, sınav, güncel siyasi gelişmeler) bağlayarak varmışlardır.

Twitter ortamındaki gerçekliği gündelik yaşam içerisindeki gerçeklikle aynı bulan katılımcılardan 1998 doğumlu Z kuşağı erkek katılımcı (K34)," Orası da gerçek dünya herkes istediğini paylaşıyor zaten, sanal ortam olabilir ama gerçek dünya herkes bütün açı̆̆ını paylaşıyor." sözü ile kullanıcıların kendileri hakkında verdikleri bilgilerden yola çıkarak Twitter ortamının gerçeği yansıttığını vurgulamıştır. 1993 doğumlu Y kuşağ1 erkek bir diğer katılımcı ise (K35) “Dünyada da her türlü insan olduğu gibi, orada da her türlü insanın yazıları olduğu için gerçeklikle bağdaştığını düşünüyorum, illa gerçek olması lazım değil insanlar yalandan da bir şey yaşıyor ama oraya da yalandan da yazıyor gerekirse" diyerek yaşamın içinde olan her şeyin Twitter'da da var olduğunu belirtmiştir. 1997 doğumlu Z kuşağı erkek katılımcı (K37), "Hayır ora biraz daha herkes ulaştığı için biz nerde ne oluyor bilemiyoruz oradakiler daha şey yani doğru, gerçeği yansıtıyor bir anda herkese ulaşabiliyorsun mesela, haberdar olduğum için gerçek buluyorum oraya bağhı yaşadığım için değil." diyerek var olan gerçekliği olaylardan haberdar olabilmesine bağlamıştır. Benzer şekilde bir diğer katılımcı gündelik yaşam gerçekliği ile farklı bulmadığı Twitter gerçekliğini dünya çapında olan olayların yer alması ile ilişkilendirmiştir:

"Yoo ora bir platform yani bir şekilde suiistimal olsa da doğru yanlı̧̧ şeyleri olsa da sonuçta orada herkes, güncele dair dünya çapında önemli olan şeyler düşüuyorsa, çok farklı değil" (K8, erkek 1976 doğumlu, X kuşağı).

Twitter kullanıcılarının davranışlarındaki gerçeklik üzerine katılımcı algısında; katılımcıların pek çoğu kullanıcıların olduklarından farklı şekilde davrandıklarını düşünmektedirler. Fakat bunun tam tersi bir durumun, kullanıcıların oldukları gibi davrandıkları düşüncesinin katılımcılarda mevcut olduğu da görülmüştür. 
Twitter'da kullanıcı davranışlarının gerçek hayatta oldukları ile aynı (benzer) olduğunu, düşünen katılımcılar, Twitter'da bireylerin aslında daha doğal olduklarını, gerçek kişiliklerini yansıttıklarını belirtmişlerdir. Tam tersi görüşte olan katılımcılarda da aslında günlük yaşam içerisinde kullanıcıların kendi gerçek kişiliklerini yansıtmadıklarını Twitter'da ise gizledikleri gerçek kişiliklerini yansıttıklarını düşündüğünü belirtmiştir. Twitter'da katılımcıların algısı genel olarak değerlendirildiğinde takip edilen kişi, edinilen enformasyon ve katılımcıların sosyal çevreleriyle etkileşim ve iletişim biçimlerine bağlı olarak algılanan gerçekliğin katılımcıdan katılımcıya değişiklik gösterdiği görülmektedir.

\section{5. (Tema 5)- Platform Karşılaştırma}

Katılımcılarla yapılan görüşmelerde her dört katılımdan biri Twitter'ı diğer popüler sosyal ağ siteleri ile karşılaştırmıştır. Bu karşılaştırmalarda Twitter'ın gerçeklik, güvenirlik ve doğruluk açılarından değerlendirilmesi yapılmıştır.

1996 doğumlu, Z kuşağı erkek katılımcı (K23), “Ben öyle çok da farklı olduklarını düşünmüyorum, yani Twitter daha çok insanın diğer Instagram ve Facebook'a göre daha çok mutluluklarım yansıtmıyor da yok hep üzüntülerini yansıtıyor kederlerini paylaşıyor, ifadeler kontrol edildiği zaman bunlar anlaşılır yani bu benim dikkatimi çekmişti bir ara yani insan fazla mutlu olduğu şeyleri Instagram'da paylaşıyor, fotoğrafla paylaşıyor ama üzüntülü olduğunda sinirli olduğunda feryat ettiği zaman bunu hep Twitter aracilığıyla yazıyor, bu benim dikkatimi çekmişti. Yani daha çok insanlar gerçek hayattaki üzüntülü anlarını Twitter'da paylaşıyor diyebiliriz yani, bende bu şeye uyuyorum Instagram'da hiç kötü şeyleri paylaşmadım, Twitter'da eleştirilerimi öfkemi paylaşırım" diyerek sosyal medya kullanıcılarının duygu durumlarına göre mecra değiştirerek paylaşım yaptıklarını belirtmiştir.

1994 doğumlu Y kuşağı kadın katılımcı (K26), "Parodi hesapları geçersek kişisel benim gibi isim soy isim kullanıyorlarsa, Instagram olsaydı konu kesinlikle yansıtmıyor derdim ama Twitter olduğu için insanlar kendi duygu düşüncelerini, tepkilerini daha rahat dile getirebiliyorlar, Son dönemde YKS ertelensin diyorlar mesela bir öğrenci Twitter hesabı açıp duygu ve düşüncelerini dile getirmek, resmi kanallara daha çabuk ulaşmak için, tepkisinin görülebilmesini sağlaması için kullanıyorlar. Fotoğraf platformlarının-Instagram, Pinterest gibi-gerçeği yansıtmadığın düşünüyorum." diyerek bireylerin Twitter'da duygu ve düşüncelerini daha rahatlıkla dile getirebildiklerini ve bu nedenle de gerçek kimliklerini yansıttıklarını düşündüğünü belirtmiştir. 1976 doğumlu, X kuşağı erkek katılımcı (K8), "Şahısların güvenilirliği ile ilgili, kurumsal Twitter ile ilgili değil de diğer Facebook, diğer Instagram gibi arkasını takip edemeyeceğimiz yerlere göre on tane hesap var gerçekliğini kimin olduğunu bilemiyorsun belli bir isim üzerine ama burada biraz daha ciddi diğer platformlara göre" diyerek kullanıcıların diğer platformlara göre daha gerçek kimlikleri ile yer aldığı düşüncesi ile Twitter'ı daha ciddi ve gerçekçi bulmuştur.

Genel olarak Twitter'ı diğer sosyal ağ siteleri ile karşılaştıran katılımcılar, bireylerin Twitter'da diğer platformlara göre sık fotoğraf paylaşımı yapmamaları, duygu ve düşüncelerini daha rahat ifade etmeleri ve yaşadıklarını Twitter'a yansıtmalarını dikkate alarak Twitter'ı daha gerçekçi bir ortam olarak nitelendirmişler. 


\section{6. (Tema 6)- Paylaşılan Gerçeklik}

Katılımcılar genel olarak Twitter profillerinde kendi gerçek isim ve fotoğraflarını kullandıklarını belirtmişlerdir. 1972 Doğumlu X kuşağı erkek katılımcı (K5) “Kullanıyorum başka kullanmam farklı bir kullanıcı adı saçma geliyor yani işte oradan anlıyoruz ki kim olduğunu bilmiyoruz sahte olduğunu oradan anlıyoruz." ifadesiyle Twitter'da gerçek kimliği ile yer aldığını belirtmiştir. Katılımcıların geneli Twitter'da yaptıkları paylaşımlarının da gerçek kimliklerini, duygu ve düşüncelerini yansıttığını belirtmişlerdir. 1996 Z kuşağı erkek katılımcı (K23), "Kendi duygu ve düşüncelerimden oluşuyor beni yansıtmayan şeyleri paylaşmıyorum fikirlerim olsun düşüncelerim olsun, beğeniler de aynı şekilde" diyerek kendi düşüncelerinden oluşan paylaşımlar yaptığın belirtmiştir. Bazı katılımcılar ise siyasi nedenlerle ya da toplumsal baskı hissetmeleri nedeniyle duygu ve düşüncelerini rahatlıkla Twitter da dile getiremediklerini belirtmişlerdir.

Katılımcılardan profil fotoğrafını kimliğini yansıtır şekilde paylaşmak istemeyen kullanıcıların paylaşmama nedenleri arasında güvenlik, tanınmama, rahatsız edilmeme, korunma, başkaları tarafından takip edilmek istememe gibi nedenler yer almaktadır. Katılımcılardan birkaç kişi, Twitter'da hakarete uğrayabileceklerini, siyasi ve mesleki nedenlerle zarar görebileceklerini düşündükleri için kendi duygu ve düşüncelerini açıkça paylaşamadıklarını belirtmişlerdir. Örneğin 1973 doğumlu, erkek X kuşağı katılımcı (K7), "Kendi duygu düşünceme göre de paylaşım yapıyorum dolaşırken hoşuma giden video vb. paylaşımları da paylaşırım. Her konu hakkında da yazamıyorum, yazmak istiyorum fakat mesleğimden dolayı geri çekiliyorum. Milletçe toplumda eleştiriye tahammülümüz yok, yanlışları söylendiğinde hakaret olarak algılanıyor, beni de eleştirseler ben de hakaret olarak kabul ediyorum. Sonuçta her canımızın istediğini yazamıyoruz." demiştir. Katılımcılardan ikisi ise çift hesap kullandığını belirtmişlerdir. Çift hesap kullanan 1991 doğumlu Y kuşağı kadın katılıma (K31) ise "sahtedeki ondan oluyor gerçekteki ondan olmuyor, kendi gerçek ismimin yer aldığı hesapta sadece takip fake olanda daha çok eleştiri" diyerek gerçek kimlikli hesabında kendi duygu ve düşüncelerini paylaşmadığını, sahte kimlikli hesabında ise eleştirel tarzda duygu ve düşünce paylaşımı yaptığını belirtmiştir.

\section{7. (Tema 7)- Yankı Odası}

Sosyal medya araçları ve pek çok internet sitesi uyguladıkları algoritmalar ile internet kullanıcıların istemedikleri mesajları filtrelemelerine ve bireylerin kendileri ile aynı görüşte olan kullanıcılarla bir yankı odasına hapsolmalarına neden olmaktadır. Bu durum kamuoyu algısının belirlenmesinde de önemli rol oynamaktadır. Yankı odası etkisi, kullanıcıların kendi mevcut görüşlerini güçlendiren bilgilerle karşılaşılmasını ve bu bilgilerin özellikle seçilmesini sağlayarak bu görüşlerinin genel kabul olarak görülüp doğru olarak nitelendirilmelerine de neden olmaktadır. Katılımcıların Twitter'da takip ettikleri kişilerde aradıkları düşünce yapısına veya katılımcıların takip tercihine bakıldığında katılımcıların yarısı Twitter' da genelde kendi düşüncelerine benzer kişileri takip ettiklerini ifade ederlerken diğer yarısı da kendi düşüncelerinden farklı fikirlere sahip kişileri de takip ettiklerini ifade etmişlerdir. 1966 doğumlu, X kuşağı kadın katılımc1 (K13), "evet kendi düşünceme uygun kişileri takip ediyorum genelde farklı paylaşımlar rahatsız ediyor" diyerek Twitter'da karşısına çıkan farklı düşüncelerden rahatsızlık duyduğunu dile getirmiştir. 1993 doğumlu Y kuşağı kadın katılımc1 (K28), "Şöyle genellikle evet farklı düşünce olunca insanın hoşuna gitmiyor ya da cevap verme gereği duyuyorsun insanlarda bu konularda 
çok anlayışlı olmuyor açıkçası, ben o yüzden genelde yüzde doksan beş kendim gibi düşünen insanları takip ederim. "diyerek farklı görüşlere karşı düşüncesini ifadesi etmiştir. 1996 doğumlu Z kuşağı kadın katılımcı (K45), "İlgimi çeken hesaplar ya da beni eğlendiren görmekten hoşlanacağım şeyler paylaşan kişileri takip ederim, ya işte herkes bunu takip ediyor ben de takip edeyim öyle bir düşüncem yok." diyerek kendi ilgi ve alakasına göre paylaşım yapan Twitter kullanıcılarını takip yaptığını belirtmiştir.

Twitter hesaplarında takip ettikleri kişiler arasında farklı görüşlerde olan Twitter kullanıcılarını da takip etme tercihinde bulunan katılımcılar ise merak, doğru bilgiye ulaşma, onlardan da ilham alabilme gibi nedenlerle farklı görüşe sahip kişileri de takip ettiklerini ifade etmişlerdir. 1994 doğumlu Y kuşağı, erkek katılımc1 (K17), "Karşı görüşü de takip ederim, mesela să̆ görüşlü isem sol görüşü de takip ederim. Onların benim hakkımda söyledikleri önemli olduğu için takip ederim." diyerek kendi düşüncesinden farklı fikre sahip kişileri merak duygusu ile takip ettiğini belirtmiştir. 1993 doğumlu, Y kuşağ1 erkek katılımc1 (K21), "Yok buna karşıyım son zamanlarda her kesimden bilgi almak istiyorum her kesimden bilgim olsun istiyorum." diyerek sadece kendi görüşü ile aynı görüşe sahip kullanıcıları takip etmeye karşı olduğunu, her kesimden bilgi alınması gerektiğini düşündüğünü ifade etmiştir. 1984 doğumlu, Y kuşağ1 erkek katılımc1 (K22), "Yo hayır asla sağmış solmuş siyasi düşüncesi şuymuş buymuş kesinlikle o derde girmemişimdir, o tarz şeylere girmem insan odakl her yönden takip ediyorum." ifadesiyle takipçi ayırmadı̆̆ını belirtmiştir. 1988 doğumlu Y kuşağ kadın katılımcı (K30), "Özellikle her görüşten takip ediyorum ki haber ne kadar doğru ona bakmak için” söylemi ile edindiği enformasyonun doğruluk oranını farklı görüşlere sahip kişileri takip ederek karşılaştırmalı şekilde belirlediğini ifade etmiştir. 1972 doğumlu, X kuşağı erkek katılımcı (K5), "Yoo, illaki benim bir düşüncem vardır ama ben benim gibi düşünmeyen insanlarn da takip ediyorum onlarn penceresinden de bakmaya çalı̧̧ıyorum." diyerek sadece kendi görüşüne sahip kişileri takip etmediğini farklı düşünen insanlarla empati yapabilmek amaçlı farklı görüşleri de takip ettiğini belirtmiştir. 1971 doğumlu, X kuşağı erkek katılımc1 (K6), "Yok ben karma, şöyle hepimiz belli bir siyasi düşünceye sahibiz beğendiğimiz düşünceler de var beğenmediklerimizde, tamamıyla benim görüşümü paylaşmayan zıt düşünceli bir insan da okumak istiyorum, onun takip ettiği peşinden koştuğu emek sarf ettiği ömrünü tükettiği o siyasi fikri yapısını öğrenmek için takip etmem gerekiyor, bu açıdan ediyorum." sözleri ile kendi ile zıt düşünceli insanların fikri yapısı hakkında bilgi sahibi olmak amaçlı takip yaptı̆̆ını açıklamıştır.

Katılımcıların Twitter'da kendilerini ile aynı düşünce yapısında olmayan insanları takip etme hakkındaki düşünceleri genel olarak değerlendirildiğinde, bireylerin kendileri ile aynı düşünce yapısında olmayan insanların da fikirlerine önem verilmesi ve dikkat edilmesi gerekliliğindeki düşünce yapısını ön plana çıkardıkları görülmektedir. Bu bağlamda katılımcıların yankı odası etkisine daha az maruz kalabilecekleri öngörülebilir.

\section{8. (Tema 8)- Farklı Fikirlere Tahammül}

Katılımcılar Twitter'da kendi düşünce yapısına uymayan kullanıcılara ve kullanıcıların paylaştıkları içeriklere karşı tutumları takipten çıkma/engelleme, merak ederek takip etme, öfkelenme ya da saygı duyma şeklinde olmaktadır. Takipten çıarma ve engelleme düşüncesine sahip 1976 doğumlu X kuşağı kadın katılımcı (K12), "belli bir süre ona zaman veriyorum çok zıt uç noktadaysa takip etmiyorum" ifadesinde bulunmuştur. Farklı dünya görüşü ya da düşünce yapısı içeren paylaşımlara ve bu paylaşımları yapan kişilere karşı saygı duyduğunu belirten 1964 doğumlu X kuşağı erkek katılımcı 
(K2), "Ya şöyle oluyor ne bunlar ne işe yarıor ne olacak bu kadar kitap diyenlere saygı duyuyorsunuz çünkü onun dünya görüşü öyle, siz kalkıyorsunuz benim 70 bin tane kitabım diyorsunuz ya da bir sergi açıyorsunuz ya da bir kitabı tanıtıyorsunuz ya da bir fotoğrafı paylaşıyorsunuz gayet normal onun dünyası da çok farklı" ifadesiyle farklı fikirlere saygısı olduğunu belirtmiştir. 1998 doğumlu Z kuşağı erkek katılımcı (K34), "anladıysam takipten çıarırım niye takip edeyim hayır yani daha fazla görüp de sinirlerim mi bozulsun, mantıkl olan bu o adamı sürekli göreceksin ana ekranda, keşfette görünce sinirlenip engellersin yani" diyerek farklı düşünce yapısından hoşlanmadığını ve farklı düşünce yapısına sahip kişilerin onu sinirlendirdiği belirtmiştir. 1979 doğumlu X kuşağı kadın katılıma (K10), "Hayır çünkü onun da ne yaptığını bilmek isterim” ifadesiyle farklı fikir yapısına sahip kişilerle karşı merak duyduğunu onlar hakkında bilgi sahibi olmak istediğini belirtmiştir.

\section{9. (Tema 9)- Çoğunluğun Doğrusu}

Katılımcıların Twitter'da trend olan ve çok sayıda destekçi bulan bir konu üzerinden yapılan paylaşımları destekleme konusunda yaklaşımları ya "desteklemem" ya da "aynı fikirde isem desteklerim" şeklinde olmuştur.

Desteklemem diyen 1996 doğumlu Z kuşağı kadın katılımcı (K45), "hiç öyle şeylere girmem yok, gerek yok çok bi şeylere ilerlediğimizi düşünmüyorum oralardan" ifadesiyle hiçbir şekilde destek vermediğini belirtmiştir. 1993 doğumlu, Y kuşağı kadın katılımcı (K28), "Yok bana garip gelir hatta bu kadar saçma bir şeyi bu kadar insan ne kadar desteklemiş diye hiç etkilenmem benim için yanlışsa yanlıştır. Çoğunluğun paylaştı̆̆ benim düşündüğ̈̈̈mden farkh bir düşünceye yorum yapmam ama destek de vermem." diyerek çoğunluğun düşüncesine katılmadığını belirtmiştir. Çoğunlukla aynı fikirde ise paylaşımlara destek vereceğini söyleyen katılımcılardan 1993 doğumlu, Y kuşağ1, erkek katılımc1 (K21), "bana uygunsa düşünürüm kendi kafamda teraziye ölçerim. Doğru mu bana uygun mu çünkü sürü psikolojisini sevmiyorum ben biri öyle diyor diye ben de paylaşmam bana uygunsa o konudaki fikrimi belirtirim paylaşırım onun dışında pek yapmam." şeklinde görüş belirtmiştir. 1982 doğumlu, Y kuşağı, kadın katılımcı (K27), "bende aynı fikirde isem desteklerim her şeyi desteklemem, vatan millet, şehit konularında destek veririm" demiştir.

\section{0. (Tema 10)- Paylaşımların Düşünce Değișimine Etkisi}

Twitter'da yer alan paylaşımların ve katılımcıların ilgilendikleri konu ya da kişiler hakkındaki paylaşımlarda yer alan içerik ve yorumların katılımcıların ilgilendikleri konu ya da kişiler hakkındaki düşünceleri üzerine etkili olup olmaması ve onlar hakkında fikirlerinin değişmesine sebep olup olmaması noktasında katılımcı düşüncesi ikiye ayrılmaktadır. Katılımcıların bir kısmı düşüncelerini "etkiler" olarak beyan ederken diğer kısmı ise "etkilemez" şeklinde belirtmiştir. Ayrıca katılımcılar duygu ve düşüncelerinin etkilenip etkilenmemesinin o anki duruma, konuya ve kişiye göre değişiklik göstereceğini belirtmişlerdir. 1993 doğumlu Y kuşağı kadın katılımcı ise "bu biraz konuya bağh olarak

| 760 | değişir ama Twitter gündemi bana gerçekçi ve doğru geliyor seviyorum o ortamı, büyük bir konu olay skandal olur ise o zaman değişir tabi. Kişi hakkında da etkilenebilirim ama şöyle değil hiç sevmediğim kişiye karşı birden sevgi beslemek şeklinde olmayabilir ama o seomeyişim kalkar ortadan yani nötrleşir kırılır oluşmaz." ifadesiyle düşünce ve duygu değişiminde konunun önemini belirtmiş, paylaşımlardan etkilenebileceğini dile getirmiştir. 1981 doğumlu, Y kuşağı kadın katılımcı (K32), “Ben araştırma konusunda iyiyim güzel araştırırım. Bir kişi ile 
ilgili bir haber var ise öncelikle o haberin doğruluğuna bakarım, kendimde süzgeçten geçiririm eğer aklıma yatarsa evet olabilir dersem değgişebilir, olumsuz düşündüğüm şeyler olumluya da dönebiliyor. Bir de şu var takip ettiğim birçok insanda bunu yaşadım, ünlülerden sevdiğim kişileri takip ettiğimde hiç sevmediğim birini çok sevdiğim, çok sevdiğim birinden nefret ettiğim olmuştur paylaşımlarından dolayı..." diyerek paylaşımın gerçek olup olmadığını araştırdığını, doğruluğundan emin olduktan sonra bir karara vararak düşüncelerinde değişikliğe gittiğini belirtmiştir. 1993 doğumlu, Y kuşağı erkek katılımc1 (K21), "Yani şöyle sempati duyduğum hayran olduğum biri hakkında kötü bir düşünce olduğu zaman açıklayıcı şekilde böyle o konuyu açıklayıcı şekilde onu kötüleyen şey olsun etkilenirim acaba böyle mi gibisinden ama belli bir süre galiba yine devam ederim. Kötü düşüncem varsa doğru düzgün paylaşımlar yazılar gördü̆̆̈̈m zaman yani gerçeği gördüğüm zaman düşüncelerim, düşüncem değişir, etkilenirim kötü düşünmem en azından etkileniyor insan ister istemez gerçeği gördü̆̆üm zaman." ifadesiyle düşüncesini dile getirmiştir. Katılımcıların pek çoğu da düşüncelerinin etkilenmesi noktasında hakkında paylaşım yapılan kişiyi tanıma ya da kişiye karşı bir sempati duyulması veya yakınlık derecesi olması durumunun o kişi hakkında duygu ve düşüncelerini çok etkilemediğini fakat olumsuz düşünülen, hoşlanılmayan ya da yakından tanınmayan kişiler hakkında yapılan paylaşımların ise duygu ve düşüncelerini etkilediğini belirtmişlerdir.

Twitter'daki paylaşımların düşünce ve duygularını etkilemeyeceğini dile getiren katılımcıların bir kısmı tanıdıkları kişilere karşı düşüncelerinin etkilenmediğini olumsuz düşündükleri kişilere karşı fikirlerinin değişebileceğini ifade etmişlerdir. Örneğin 1975 doğumlu X kuşağı erkek katılımc1 (K3), "Değişmez tabi ki, olumsuz düşündüğ̈̈m bir kişi ya da konunun gerçek olduğunu bilirsem değģsir yoksa yine değişmez" diyerek bu konudaki fikrini açıklamıştır. Twitter'daki paylaşımların düşünce ve duygularını etkilemeyeceğini dile getiren katılımcıların diğer kısmı ise sevmedikleri kişi ya da kişiler hakkında Twitter'da yer alan olumlu paylaşım ve içeriklerin o kişi ya da kişiler hakkında duygu ve düşüncelerini olumlu yönde kesinlikle etkilemeyeceğini ifade etmişlerdir. 1978 doğumlu X kuşağı kadın katılımc1 (K9), "Hayır etkilemez, önyargıya karşıyım ben insanları tanıyorsam seviyorsam sayıyorsam benim için değerli ise o kişi ya da konu hakkında söylenenler beni etkilemez başkasının söylediğine kulak asmam, bir insanı da seomiyorsam onu ne yaparsa yapsın ne kadar göklere zembille çıkarsalar da sevmiyorumdur ona karşı düşüncelerimi etkilemez değiştirmez, hayatımda gri yoktur ya siyah ya beyazdır." ifadesiyle bu düşünceyi açıklamıştır. Katılımcıların bazıları ise Twitter'da ilgilendikleri bir konu ya da kişi ile ilgili paylaşımlarda yer alan içerikler ve yorumların, paylaşıma konu olan kişi ya da mesele hakkındaki düşüncelerini etkileme ve fikirlerini değiştirmeleri noktasında kendi görüşlerini gözden geçireceğini düşünmektedirler.

\section{1. (Tema 11)- Yalana Bakış}

Katılımcıların yalan söylemek hakkında düşünce biçimleri "yalanı hoş karşılamama", "yalanı hoş görme" ve "yalanın yaygın olduğunu düşünme" şeklinde sınıflandırılabilir. Yalanı hoş karşılamayan katılımcıların pek çoğu yalan söylemenin dini inanışların belirlediği bazı durumlarda ve zorunlu haller dışında iyi bir şey olmadığı, yalanın söylenilmemesi gerektiği, doğru olmadığı, bireyler arası güveni zedelediği ve toplum yapısına zarar verdiği düşüncesi ile yalanı hoş karşılamamaktadırlar:

"Yalan niye söylensin ki bizim ne dinimizde ne kültürümüzde buna icazet verilmemiş yalan ne yetiştiğimiz toplumda var. Dünya üzerindeki hangi din olursa olsun hangi kültürde olursa olsun yalan iyi bir şey değil kötü bir şey, onun için bende herkes gibi söylemem söyleyeni de sevmem. Yalan olduğunu bilirsem söylenenin şayet o kişiye 
karşıda sosyal medyadan bahsetmiyorum sosyal medyayı zaten biliyoruz o bir çerçeve... Sosyal medya dışında bir kişinin sürekli yalan söylediğini fark edersem bundan eminsem o kişi ile ilişkilerim değişir, o kişi ile münasebetlerimde daha dikkatli davranırım." (K5, erkek, 1972 doğumlu, X kuşağı)

Yalanı hoş gören diğer katılımcıların yalana karşı yaklaşımları ise şu şekildedir;

"Hayat felsefesi söylemeyen yoktur şimdi baktığın zaman, bence yalan durumu kurtarmak için söylenebiliyor, birçok başka şeyler için de birini üzmemek için de söylenebiliyor, illa kötü bir şey değil yalan, baktığın zaman tamam karşındaki kişiyi kandırmak ama en çok kendini kandırıyorsun sonuçta gene o yüzden çok yalana karşı önyargılı değilim" (K45, kadın, 1996 doğumlu, lisans mezunu).

Katılımcıların çoğunluğu yalanı hoş karşılasa da hoş karşılamasa da yalanın toplumda çok yaygın olduğunu düşünmektedirler. Katılımcılara yalana destek verip vermeyeceklerine yönelik sorulan "kendi duygu ve düşüncelerinize uygun bir konu ya da sevdiğiniz bir kişiyi destekler nitelikte dolaşan yalan olduğunu bildiğiniz bir habere destek verir misiniz?" sorusuna karşılık olarak katılımcıların çoğu destek vermeyeceklerini söylemişlerdir. Katılımcıların yarısı Twitter'da şaka ve mizah amaçlı yalan ya da yanlış bir bilgiyi paylaşım noktasında, tweet'in eğer şaka ve mizah olduğu belliyse, zekice, kimseyi kırmayacak incitmeyecek tarzda ise, toplumun eğlenmeye, şakaya da ihtiyacı olduğu düşüncesi ile paylaşıp kendilerinin de yapabileceğini belirtmişlerdir. Katılımcıların diğer yarısı ise bu tür paylaşımları ciddiyetsiz buldukları ve şaka sevmedikleri için paylaşmayacaklarını belirtmişlerdir.

Katılımcılar Twitter'da yer alan yalan bir habere ya da Twitter'da yalan söyleyen bir kişiye karşı tutumlarını "tepki verenler" ve "tepki vermeyenler" olarak iki şekilde sınıflandırabilmektedir. Katılımcıların yapılan yalan paylaşıma karşı genel tepkileri ise, fikirlerini kibarca ya da ince bir dil kullanarak belirtme, paylaşan kişiyi takibi bırakma/şikâyet etme/engelleme, paylaşımın doğrusunu varsa belge, fotoğraf, kanıt vs. sunarak yapma şeklinde olmaktadır.

Katılımcılara yöneltilen "Hiç yalan söylediniz mi?" sorusuna cevap olarak katılımcıların geneli, gündelik yaşam içerisinde yalan söylediklerini belirtmişlerdir. Fakat katılımcıların çoğunluğu yalan söylemenin doğru olmadığını belirtmiş ve söyledikleri yalanın küçük boyutlu olduğunu ve pembe ya da beyaz yalan olarak nitelendirilebileceğini ifade etmişlerdir.

Araştırma sonucunda elde edilen veriler seçilen grup özellikleri (X, Y, Z Kuşağı) ve demografik değişkenleri açısından ayrıca nicel analize tabi tutulmuştur. Nitel araştırma sonucu elde edilen kodlar altında yapılan nicel analiz Tablo 3'te gösterilmektedir. 
Tablo 3. Demografik Değişkenler Üzerinden Verilerin Nicel Analizi

\begin{tabular}{|c|c|c|c|c|c|c|c|c|c|c|c|c|}
\hline \multirow[t]{2}{*}{ Tema $^{1}$} & \multirow[t]{2}{*}{$\begin{array}{l}\text { Demografik } \\
\text { Değişken }\end{array}$} & \multicolumn{2}{|c|}{ Cinsiyet } & \multicolumn{3}{|c|}{$\begin{array}{c}\text { Yaş-Kuşak } \\
\text { (Doğum yılına göre) }\end{array}$} & \multicolumn{6}{|c|}{ Öğrenim Durumu } \\
\hline & & Kadın & Erkek & $\begin{array}{l}1965- \\
1980 \\
(X)\end{array}$ & $\begin{array}{l}1981- \\
1995 \\
(Y)\end{array}$ & $\begin{array}{l}1996 \\
-2012 \\
(Z)\end{array}$ & $\begin{array}{l}\text { İlk } \\
\text { okul }\end{array}$ & $\begin{array}{l}\text { Orta } \\
\text { okul }\end{array}$ & Lise & $\begin{array}{l}\text { Ön } \\
\text { lisans }\end{array}$ & Lisans & $\begin{array}{l}\text { Yüksek } \\
\text { lisans }\end{array}$ \\
\hline \multirow{3}{*}{$\begin{array}{l}\text { Haberin } \\
\text { Doğruluğu }\end{array}$} & Negatif & 13 & 18 & 6 & 7 & 1 & 1 & - & 5 & 3 & 4 & 3 \\
\hline & Nötr & 3 & 1 & 2 & 3 & 6 & - & 1 & 5 & 2 & 8 & - \\
\hline & Pozitif & 8 & 5 & 8 & 6 & 9 & - & - & 5 & 2 & 7 & 3 \\
\hline \multirow{3}{*}{$\begin{array}{l}\text { Paylaşımlarda } \\
\text { Doğruluk } \\
\text { Teyidi }\end{array}$} & Negatif & 8 & 12 & 13 & 13 & 8 & - & 1 & 5 & 1 & 4 & 2 \\
\hline & Nötr & - & - & - & - & - & - & - & - & - & - & - \\
\hline & Pozitif & 16 & 12 & 3 & 3 & 8 & 1 & - & 10 & 5 & 15 & 4 \\
\hline \multirow{3}{*}{$\begin{array}{l}\text { Bilgi ve } \\
\text { Söylenti } \\
\text { Ayrımı }\end{array}$} & Negatif & 1 & 2 & 3 & 1 & 4 & - & - & 2 & 1 & - & 1 \\
\hline & Nötr & - & - & - & - & - & - & - & - & - & - & - \\
\hline & Pozitif & 23 & 22 & 13 & 15 & 12 & 1 & 1 & 13 & 5 & 19 & 5 \\
\hline \multirow{3}{*}{$\begin{array}{l}\text { Twitter ve } \\
\text { Gerçeklik }\end{array}$} & Negatif & 11 & 17 & 9 & 9 & 9 & 1 & - & 6 & 4 & 14 & 4 \\
\hline & Nötr & - & 2 & 2 & - & - & - & - & - & - & 1 & - \\
\hline & Pozitif & 13 & 5 & 5 & 7 & 7 & - & 1 & 9 & 2 & 4 & 2 \\
\hline \multirow{3}{*}{$\begin{array}{l}\text { Paylaşılan } \\
\text { Gerçeklik }\end{array}$} & Negatif & 3 & 1 & 2 & 2 & - & - & - & - & 2 & 1 & - \\
\hline & Nötr & - & - & - & - & - & - & - & - & - & - & - \\
\hline & Pozitif & 21 & 23 & 14 & 14 & 16 & 1 & 1 & 15 & 4 & 18 & 6 \\
\hline \multirow[t]{3}{*}{ Yankı Odası } & Negatif & 8 & 11 & 8 & 9 & 5 & - & 1 & 6 & 3 & 9 & 4 \\
\hline & Nötr & - & - & - & - & - & - & - & - & - & - & - \\
\hline & Pozitif & 16 & 13 & 8 & 7 & 11 & 1 & - & 9 & 3 & 10 & 2 \\
\hline \multirow{3}{*}{$\begin{array}{l}\text { Farklı Fikirlere } \\
\text { Tahammül }\end{array}$} & Negatif & 7 & 9 & 4 & 6 & 4 & 1 & - & 4 & 1 & 6 & 3 \\
\hline & Nötr & - & - & - & - & - & - & - & - & - & - & - \\
\hline & Pozitif & 17 & 15 & 12 & 10 & 12 & - & 1 & 11 & 5 & 13 & 3 \\
\hline \multirow{3}{*}{$\begin{array}{l}\text { Çoğunluğun } \\
\text { Doğrusu }\end{array}$} & Negatif & 21 & 18 & 15 & 12 & 13 & 1 & 1 & 14 & 6 & 18 & 4 \\
\hline & Nötr & - & - & - & - & - & - & - & - & - & - & - \\
\hline & Pozitif & 3 & 6 & 1 & 4 & 3 & - & - & 1 & - & 1 & 2 \\
\hline \multirow{3}{*}{$\begin{array}{l}\text { Paylaşımların } \\
\text { Düşünce } \\
\text { Değişimine } \\
\text { Etkisi }\end{array}$} & Negatif & 13 & 12 & 9 & 7 & 6 & 1 & - & 9 & 2 & 10 & 3 \\
\hline & Nötr & 1 & 3 & - & 1 & 2 & - & - & 1 & - & - & - \\
\hline & Pozitif & 10 & 9 & 7 & 8 & 8 & - & 1 & 5 & 4 & 9 & 3 \\
\hline \multirow[t]{5}{*}{ Yalana Bakış } & Negatif & 18 & 17 & 13 & 14 & 8 & 1 & 1 & 11 & 5 & 11 & 4 \\
\hline & Nötr & - & - & - & - & - & - & - & - & - & - & - \\
\hline & Pozitif & 6 & 7 & 3 & 2 & 8 & - & - & 4 & 1 & 8 & 2 \\
\hline & Toplam Kişi & & & & & & & & & & & \\
\hline & Sayısı: (48) & 24 & 24 & 16 & 16 & 16 & 1 & 1 & 15 & 6 & 19 & 6 \\
\hline
\end{tabular}

Veriler demografik bulgular üzerinden nitel olarak yorumlandı̆̆ında bazı önemli noktalar dikkat çekicidir. Twitter'da yer alan haberin doğruluğuna inanma konusunda erkek katılımcılara nazaran

1 Platform Karşılaştırma isimli tema, pozitif-negatif-nötr değişkenlerine uyarlanamadığı için, bu nicel analiz tablosunda yer almamıştır. 
kadın, $X$ ve $Y$ katılımcılara nazaran $Z$ kuşağı katılımcıların Twitter'da yer alan haberlerin doğruluğuna inandıkları görülmüştür. Twitter'da paylaşımlarda doğruluk teyidi yapma hususunda ise kadın katılımcıların erkek katılımcılara göre; $X$ ve $Y$ kuşağı katılımcıların da $Z$ kuşağı katılımcılara göre yapılan paylaşımlarda doğruluk teyidi yapmaya daha fazla dikkat ettikleri görülmüştür.

Katılımcıların Twitter'da var olan gerçeklik algısına bakıldığında kadın grubu katılımcıların erkek grubu oluşturan katılımcılara göre Twitter'ı sanal bir ortam olmaktan ziyade içinde yaşanılan gerçekliğe uygun daha gerçekçi bir ortam olarak değerlendirdikleri görülmüştür. Eğitim düzeyleri dikkate alındığında katılımcıların eşit dağılım göstermediği görülmüştür. Bu nedenle eğitim düzeyi açısından analizde oranlar göz önünde bulundurulmuştur. Buna göre eğitim düzeyi arttıkça Twitter'da var olan gerçekliği içinde yaşanılan gerçeklikle aynı olarak düşünen katılımcıların pozitif bakış açılarının düştüğü görülmektedir.

Twitter'da yankı odası etkisi açısından katılımcıların bakış açısı ele alındığında kadın ve erkek katılımcıların genelde farklı fikirlere açık oldukları, kendileri gibi düşünmeyen insanlara saygı duydukları ve farklı düşünce yapısına sahip insanların dünya görüşü hakkında bilgi sahibi olmak istedikleri görülmüştür. Kuşaklar açısından ele alındığında ise $X$ ve $Y$ kuşağı katılımcıların farklı düşünce yapısına sahip insanları da takip ederek siyasi, sosyal ve ekonomik olayları onların penceresinden de değerlendirmeye çalıştıkları, Z kuşağı katılımcıların daha çok kendi düşüncesine sahip sosyal çevre ve yakın arkadaşlarını takip ettikleri görülmüştür.

Katılımcıların yalana bakış açıları ise kadın ve erkek katılımcılar açısından benzer nitelikte negatif bir bakış açısıdır. Kuşaklar arası değerlendirme yapıldı̆̆ında ise genel olarak X ve Y kuşă̆ı katılımcılar yalanı toplum ve bireyler açısından zararlı sonuçları olması nedeniyle olumsuz karşılamakta, Z kuşağı katılımcıların geneli ise yalana karşı daha hoşgörülü yaklaşmakta ve yalanı bazen bir kurtarıcı bazen de vazgeçilmez bir olgu olarak değerlendirebilmektedirler.

\section{Sonuç}

Araştırma post-truth dönemde Twitter kullanıcılarının hakikate bakışını ele almaktadır. $\mathrm{Bu}$ bakımdan çalışmada öncelikle post-truth dönem, özellikleri ve post-truth dönemde sosyal medyanın kullanıcılar üzerindeki etkileri açıklanmıştır. Çalışmada hakikat sonrası dönemde Twitter kullanıcılarının hakikate bakışını araştırmak amacıyla yarı yapılandırılmış soru formundan elde edilen görüşme verileri NVivo programında analiz edilmiştir. Elde edilen bulgulara göre katılımcılar genel olarak Twitter'ı en son haberleri, dünya ve ülke gündemini takip etmek amaçlı kullanmaktadırlar. Genel olarak sosyal medya ortamlarına karşı bir güvensizliğin hâkim olduğu katılımcılar Twitter'da yer alan bilgi ve haberlerin çarpıtılarak sunulması, diğer kullanıcıların kendi dünya görüşlerine göre olayları yorumlamaları gibi nedenlerle Twitter'da da bir bilgi kirliliği olduğunu düşünmektedirler ve yer alan

| 764 | paylaşımların doğruluğundan şüphe duymaktadırlar. Ayrıca Twitter'ı diğer sosyal medya platformları ile karşılaştıran katılımcıların geneli Twitter' ${ }^{\prime}$ diğer sosyal platformlarına göre resmi bularak daha güvenilir olarak nitelendirmektedir. Twitter'da yer alan bilgileri doğrulama konusunda katılımcı görüşleri genel olarak değerlendirildiğinde, Twitter'da yapılan paylaşımın konusuna olan ilgi düzeyi doğrulama noktasında önem arz etmektedir. Katılımcıların konuya ilgi düzeyleri yüksekse konu 
dikkatlerini çekmekte ve doğrulama yapmaktadırlar fakat konuya olan ilgi düzeyi düşükse doğrulama yapma gereği duymamaktadırlar.

Katılımcılar Twitter'da bilgi ve söylenti ayrımını paylaşımın resmiyete dayalı olup olmamasına bakarak gerçekleştirmektedirler. Katılımcıların Twitter'da var olan gerçekliğe bakış açıları Twitter'ın sanal alem olduğu ve gündelik yaşam içindeki gerçeklikten Twitter' da var olan gerçekliğin farklı olduğu şeklindedir. Katılımcılar bu düşünceye yalan, yanlış, abartılmış ve çarpıtılmış içeriklerle karşılaşmalarından varmışlardır. Twitter'ın gündelik yaşam gerçekliğini yansıttığı görüşünde olan katılımcıların ise bu bakış açısına Twitter'da, kullanıcıların özellikle resmî kurumlara seslerini duyurmaya yönelik yaptıkları paylaşımlardan yola çıkarak ulaştıkları görülmektedir.

Twitter'da kullanıcı davranışlarının gerçeği yansıtmadığı görüşünde olan katılımcılar, birey davranışı hakkında olumsuz bakış açısına sahiptirler. Pek çok bireyin Twitter'da gerçek kimliklerini yansıtmadığı farklı şekilde davranış sergilediği düşüncesinde olan katılımcılar, bu kanıya Twitter kullanıcılarının günlük yaşam içerisinde söylemeyeceği sözleri Twitter ortamında rahatça dile getirebilmelerinden yola çıkarak varmışlardır. Katılımcılardan bir kısmı, Twitter'da pek çok bireyin aslında günlük yaşam içerisinde gizlediği gerçek kimliklerini burada ortaya çıardıkları düşüncesindedir.

Katılımcıların Twitter'da genel olarak gerçek kimlikleri ile yer alan ve genel olarak kendi duygu ve düşüncelerini paylaştıklarını ifade eden katılımcıların kimi zaman toplumsal baskı, eleştiri, linç, mesleki zarara uğrama gibi nedenlerle duygu ve düşüncelerini rahat dile getiremedikleri, siyasi eleştiri ve paylaşım yapmaktan çekindiklerini ifade etmeleri de dikkate değer bulgular içinde yer almaktadır. Genelde yakın arkadaş ve sosyal çevrelerini Twitter'da takip eden katılımcıların Twitter algoritması da değerlendirmeye alındığında bir yankı fanusu içinde oldukları düşünülebilir. Katılımcıların geneli farklı fikirlere açık olduklarını ifade etmişlerdir. Katılımcıların Twitter'da ilgilendikleri kişi ya da konu hakkında yer alan paylaşımlardan, yorumlardan etkilenmeleri çok söz konusu olmamaktadır. Fakat kişi ya da konu hakkında yeterince bilgi sahibi olmama, kişiyi yakından tanımama ve önyargı sahibi olma gibi faktörler katılımcıların paylaşımlardan, yorumlardan etkilenmelerine ve düşünce değiştirmelerine neden olmaktadır.

Araştırmaya katılan katılımcıların yalana bakış açılarına bakıldığında katılımcıların hayatında yalan vazgeçilmez bir konumdan küçükken söylenebilen, zorunlu hallerde faydalanılan, beyaz ya da pembe olarak nitelendirilebilen bir konuma farklı boyutlarda yer almaktadır. Katılımcılar Twitter'da yalan söylemediklerini buna ihtiyaç ya da gerek duymadıklarını ifade etmişlerdir. Günlük yaşam içinde yalan söyleyebildiklerini ifade eden katılımcıların yalana bakış açıları farklılık göstermektedir. Bazı katılımcılar yalanın zorunlu haller de dahil hiç söylenmemesi gereken bir şey olduğu düşüncesinde iken bazı katılımcılar için yalan hayatta vazgeçilemez bir araç olarak görülmektedir. Katılımcıların bazıları ise küçük yaşlarda yalan söylediklerini fakat olgunlaştıkça ya da daha bilinçli hale geldikçe, yalanın güveni sarstığı, toplumsal düzeni bozduğu ve insan ilişkilerine zarar verdiğini görüp yalandan uzaklaştıklarını, yalanı hoş karşılamadıklarını ve yalan söylememeyi kendilerine düstur edindiklerini ifade etmişlerdir. Bazı katılımcılar açısından ise yalanın hangi hallerde ve ne amaçla söylendiği önem taşımaktadır. Bu 
katılımcılar yalana karşı çok katı bir tavır sergilememekte ve yalanı hoş karşılayabilmektedirler. Katılımcıların geneli ise yalanın toplumda çok yaygın bir şekilde söylendiğini düşünmektedir.

Tüm bu bilgi ve bulgulardan hareketle hakikat sonrası dönemin ortaya çıkışında ve yeni medya kullanıcılarının hakikate bakış açısında yeni iletişim teknolojileri ve dijital devrimin etkisi yadsınamaz bir gerçek olarak karşımıza çıkmaktadır. Bu minvalde post-truth dönemde hedef kitle bakış açısını dikkate alarak yol haritası belirleyen kurum, kuruluş ve halkla ilişkiler uygulayıcıları için gösterdikleri sağduyu ve dürüstlük, uzun vadede olumlu imaj ve güven şeklinde geri dönüş kazanacaktır. Araştırma sınırları ve gelecek araştırmalara yol göstericilik açısından değerlendirildiğinde; araştırmanın sonuçları, ilgili örneklem grubuyla gerçekleştirilen mülakat tekniği ile sınırlandırılmıştır. Gelecek araştırmalar daha geniş bir örneklem grubu ile daha çok katılımcıya uygulanabileceği gibi farklı demografik değişkenler üzerinden daha az örneklem grubuna da uygulanarak benzer araştırma sonuçları birbirleriyle karşılaştırabilir.

\section{Etik Kurul İzni (Gerekliyse)}

Bu çalışma için etik kurul izni Erciyes Üniversitesi Sosyal ve Beşerî Bilimler Kurulu'nun 30/06/2020 tarih ve 93 numaralı kararı ile alınmıştır.

\section{Katkı Oranı Beyanı (Zorunlu)}

Yazarlar makaleye eşit oranda katkı sağlamışlardır.

\section{Çıkar Çatışması Beyanı (Zorunlu)}

Makale yazarları aralarında herhangi bir çıkar çatışması yoktur.

\section{Destek ve Teşekkür Beyanı (İsteğe Bağlı)}

Makaleyi önemli ölçüde geliştiren yorumları için Editör ve iki anonim hakeme teşekkür ederiz.

$$
\text { 淡淡 }
$$




\section{Kaynakça}

Alpay, Y. (2019). Yalanın siyaseti (4. Bask1). Destek Yayınları.

Baudillard, J. (2014). Simülakr ve simülasyon (Çev. O. Adanır) (7. Basım). Doğu Batı Yayınları.

Bayraktar, E., \& Kaleli, F. (2007). "Sanal gerçeklik ve uygulama alanları". İçinde IX. Akademik Bilişim Konferansı Bildirileri, s. 1-6, Kütahya, Dumlupınar Üniversitesi, Akademik Bilişim, 31 Ocak - 2 Şubat 2007.

Bıçakçı, İ. C. (2016). Halkla ilişkilerin kurmaca dünyası ve hakikatin direnişi. Ütopya Yayınevi.

Cevizci, A. (2005). Paradigma felsefe sözlüğ̈̈ (6.Baskı). Paradigma Yayıncılık.

Cinelli M., Morales G., Galeazzi A., Quattrociocchi, W., \& Starnini M. (2021). The echo chamber effect on social media. Proceedings of the National Academy of Sciences 118(9), 1-8. https://www.pnas.org/content/118/9/e2023301118

Dictionary Cambridge (2021, Haziran $\quad$ 15). https://dictionary.cambridge.org/tr/s\%C3\%B6zl\%C3\%BCk/ingilizce-t\%C3\%BCrk\%C3\%A7e/real
Dictionary
Cambridge
$(2021$,
Haziran
$15)$.
Truth. https://dictionary.cambridge.org/tr/s\%C3\%B6zl\%C3\%BCk/ingilizce-t\%C3\%BCrk\%C3\%A7e/truth

Eraslan, L. (2020). Sosyal medya ve algı yönetimi (Gen.2.Baskı). Anı Yayıncılık.

Fazlığlu, İ. (2014). Hakikat mi, gerçek mi: Hangisi hakiki? http://fazlioglu.blogspot.com/2018/07/ihsanfazlioglu-hakikat-mi-gercek-mi-hangisi-hakikidir.html (Erişim Tarihi: 20.05.2020)

Ferraris, M. (2019). Yeni gerçekçilik manifestosu (Çev. K. Atakay). Kolektif Kitap.

Fox, A. (2011). Mixing it up. HR Magazine, May-2011, 22-27.

Göksu, O. (2021). Alg1 yönetimi: Geleneksel medya, siyasal iletişim ve dijital medya üçgeni üzerine. İçinde O. Göksu (Ed.). Algı Yönetimi (ss. 11-36). Literatürk Yayıncılık.

Gönenç, Ö. (2018). Medyada algı yönetimi. Der Yayınları.

Gülmen, A. C. (2020, Mart 31). Post truth çağında salgın. Inmagazine. https://www.pressreader.com/turkey/inmagazine/20200331/281509343290614.

Güner, O. (2021). Avrupa Birliği'nin dijital platformlarda dezenformasyon ve alg1 yönetimi ile mücadele politikaları. İçinde O. Göksu (Ed.). Algı Yönetimi (ss. 133-152). Literatürk Yayıncılık.

Hançerlioğlu, O. (2016). Felsefe sözlüğ̈̈. Remzi Kitabevi.

Kakutani, M. (2018). Hakikatin ölümü (Çev. C. Mizrahi). Doğan Kitap.

Keyes, R. (2017). Hakikat sonrası çă̆: Günümüz dünyasında yalan ve aldatma (Çev. D. Özçetin). Tudem Yayın Grubu.

Manning, J. (2014). Definition and classes of social media. İçinde K. Harvey (Ed.). Encyclopedia of Social Media and Politics (ss. 1158-1162). Thousand Oaks.

McIntyre, L. (2019). Hakikat sonrası. (Çev. M. F. Biçici). Tellekt Can Sanat Yayınları.

Oxford Languages (2020, May1s 14). Word of the year 2016. Oxford: Oxford University Press. https://languages.oup.com/word-of-the-year/2016/.
Oxford
Learner's
Dictionaries
$(2020$,
Temmuz
12). https://www.oxfordlearnersdictionaries.com/definition/english/post-truth?q=post+truth. 
Pariser E. (2011). The filter bubble: What the internet is hiding from you. Penguin.

Psikoloji Sözlüğü (2021, Nisan 12). Prof. Dr. Sibel Karakaş psikoloji sözlüğü. https://www.psikolojisozlugu.com/confirmation-bias-dogrulama-yanliligi.

Sayımer, İ. (2008). Sanal ortamda halkla ilişkiler. Beta Yayınları.

Şimşek A., \& Yalı S. (2019). Gerçekte(n) öyle mi olmuş post-truth zamanlarda tarihin temsili. Yeni İnsan Yayınevi.

Terzi, A. (2020, Nisan). Post-truth kavramı ve Türkçe karşılıkları üzerine. https://tdk.gov.tr/wpcontent/uploads/2020/04/\%C3\%82dem-Terzi-_-POST-TRUTH-KAVRAMI-_-7-2.pdf.

Tok, İ. (2020). Hakikat ötesi çağda yeni medyada yalan/sahte haberle mücadele. İçinde Ş. Sağıroğlu, H. İ. Bülbül, A. Kılıç, \& M. Küçükali (Eds.). Dijital okuryazarlık (ss. 455-483). Nobel Yayıncilık.

Westerlund M. (2019). The emergence of deepfake technology: A review. Technology Innovation Management Review, 9(11), 39-52.

Yalçınkaya, B., Dönmez, A., Aydın, F., \& Kayalı, N. (2018). A survey about university students' perception of post-truth on social media. Journal of Awareness, 3(4), 53-64.

$$
\text { 战战 }
$$

